\title{
CO2 emissions mitigation among energy importers and energy exporters along BRI countries. What role do renewable energy and nuclear energy play
}

Jiying Wu

Jiangsu University

Olivier Joseph Abban ( $\sim$ olivierjosephs@yahoo.com )

Jiangsu University https://orcid.org/0000-0001-9968-6361

Original article

Keywords: BRI Countries, Nuclear Energy, Renewable Energy, Energy Importers, Energy Exporters, PMG Estimation

Posted Date: August 20th, 2020

DOI: https://doi.org/10.21203/rs.3.rs-58745/v1

License: (c) (i) This work is licensed under a Creative Commons Attribution 4.0 International License.

Read Full License 
1

4

5

6

7

8

9

10

11

12 * Authors for correspondence:

13 Olivier Joseph Abban

14 E-mail address: olivierjosephs@yahoo.com

15 Jiying $\mathrm{Wu}$

16 E-mail address: wjy@ ujs.edu.cn

17

18

19

20

21

22

23

24

25

17

8

9

20

23

$$
\text { Jiying } \mathrm{Wu}^{\mathrm{a}} \text {, Olivier Joseph Abban*a }
$$

${ }^{a}$ School of finance and economic, Department of statistics, Jiangsu University, Zhenjiang 212013, PR China. 
ABSTRACT

27 Background: In achieving the goal of sustainable development (Goal 13), United Nations has related global warming to greenhouse gas emissions in recent years. Emissions of carbon dioxide, are known to be the biggest contributor to global warming. Hence this study disaggregates energy consumption that is Nuclear energy, renewable energy and fossil fuel consumption and investigates their impact on $\mathrm{CO}_{2}$ emissions along the Belt and Road Initiative.

Methods: This paper determined the cross-sectional dependency and utilized second generation panel unit root test for precise estimation. Westerlund cointegration test was used to determine the long-run equilibrium relationship among the variables. Lastly the Pooled Mean Group (PMG) estimation approach was applied to investigate the long and short run output elasticities between the variables.

Results: The results indicates that; for energy importers, $\mathrm{CO}_{2}$ emissions has a significant positive correlation with Fossil fuel and nuclear energy, while renewable energy has a significant negative correlation with $\mathrm{CO}_{2}$ emissions. For energy exporting countries, a significant positive two-way relationship amidst Fossil fuel and $\mathrm{CO}_{2}$ emissions, and a significant negative one-way causal relationship from nuclear energy and renewable energy unto $\mathrm{CO}_{2}$ emissions.

42 Conclusion: The results clearly show that in all panel grouping renewable energy contribute negatively on $\mathrm{CO}_{2}$ emissions, thus more implant of renewable system is need along the belt and road initiative. These recent methodologies employed and findings revealed that in a pollution reduction tender, causal affiliations are affected in a tender to reduce emissions along with long and short-term estimated effects among employed variables by the energy groupings of Belt and

47 Road countries. Exporters, PMG Estimation. 


\section{Introduction}

55 Economic cooperation, Individual countries as well the United Nations (UN), in other to 56 achieve the sustainable development goals (goal $13^{1}$ ) have linked global warming to greenhouse 57 gas $(\mathrm{GHG})$ emissions in recent years. The emissions of carbon dioxide $\left(\mathrm{CO}_{2}\right)$ is believed as the main contributor to global warming among other GHG (Liu et al. 2016). For the past two decades, developed and developing countries, have employed for their economic growth purposes fossil energy intensively in almost all economic sectors such as manufacturing industry, agriculture and transport (Schandl et al. 2016). This therefore has headed to $\mathrm{CO}_{2}$ emissions in almost all parts of the world. Since energy consumption is a major contributor to economic growth and as well the major contributor to environmental pollution, Begum et al. (2015), expanding production technologies based on renewable and nuclear energy will significantly abridge greenhouse gas emissions (Irandoust 2016). Economics literature recently have discussed the linkages between

$66 \mathrm{CO}_{2}$ emissions with economic growth, renewable energy and nuclear energy (Baek 2015; Cai et al. 2018; Dong et al. 2018b; Ito 2017; Long et al. 2015; Omri et al. 2015). The results in general indicate a strong relationship amongst renewable energy consumption and economic growth, amongst nuclear energy use and economic growth, and also amongst $\mathrm{CO}_{2}$ emissions and economic growth. However, Baloch et al. (2019) have stated that the debate is still not clear about renewable energy and nuclear energy mitigating pollution of environment.

\footnotetext{
${ }^{1}$ Goal 13: Take urgent action to combat climate change and it impacts. Levels of carbon dioxide (CO2) and other ambient greenhouse gases rose to new levels in 2019. Each nation on each continent is affected by climate change. It disrupts national economies, and it impacts lives. Climate patterns change, sea levels rise and climate events become more extreme. The Paris Agreement, adopted in 2015, aims to reinforce the global response to the climate change challenge by holding a global temperature increase well below 2 degrees Celsius above pre-industrial levels this century. The Agreement also seeks to improve countries' ability to cope with climate change impacts through adequate a new technology system, financial flows and an improved capacity building process.
} 
Renewable energy usage, such as geothermal energy, solar energy, wind power, biofuels and

73 biomass power and other has increased about 10\% that is $24 \%$ in 2018 from $14 \%$ in 2002

74 (Petroleum 2018). Renewable energy technologies have gained popularity into economies in

75 developed and developing countries since it cheaper, more reliable and more accessible (IEA

76 2015). In 2015, developing countries invested US \$156 billion in renewable energy, an increase

77 of $19 \%$ over 2014 and more than developed countries' total investment in renewable energy (Ren21

78 2016). This was the first, investment into renewable energy in developing economies exceeded

79 that in developed economies (Adib et al. 2015). Researchers such (Bilgili et al. 2016; Sebri 2015)

80 found a one way causal effect from renewable energy to $\mathrm{CO}_{2}$ emissions in their study in 17 OECD

81 countries and BRICS countries respectively. Others such as (Dogan and Seker 2016; Jebli et al.

82 2016) observed two way causal effect between renewable energy consumption and $\mathrm{CO}_{2}$ emissions

83 in $15 \mathrm{EU}$ countries and 25 OECD countries respectively.

84 On the other side, the use of nuclear power is regarded as the alternative energy source to allot

85 the high oil prices and reduce dependence on other countries for energy needs (Hewitt and Collier 86 2018). Oil and gas usage show that the world's energy demand is growing fast, reserves could run

87 out in generations to come, alternative resources are scarce and security of energy supplies is vital.

88 In response to these challenges, considering long-term development and environmental strategy,

89 nuclear energy consumption is a sure way Hori (2000). For the past decade, researchers have

90 studied the association between nuclear power and $\mathrm{CO}_{2}$ emissions. (Jaforullah and King 2015;

91 Saidi and Mbarek 2016) respectively proved that no causal relationship amidst nuclear energy and

92 carbon dioxide emission in the US and 9 developed countries using used vector error correction

93 model (VECM) Granger causality method. Their results again confirmed the growth hypothesis in

94 these regions. However, (Menyah and Wolde-Rufael 2010; Richmond and Kaufmann 2006) found 
one way causal effect from nuclear energy to $\mathrm{CO}_{2}$ emissions in the US and in OECD and non-

\section{OECD countries.}

In as much as the relationship between $\mathrm{CO}_{2}$ emissions, renewable energy and nuclear energy have been studied and reported, analysis on countries being energy importers and exporters along the BRI remain unclear. Responding to this deficiency, this study propose the relevance in analyzing the energy classifications of countries along the BRI. By exploring links between these variables, researchers may be able to help determine whether renewable energy or nuclear energy is the best in mitigating $\mathrm{CO}_{2}$ emissions in these groups. If renewable energy or nuclear energy helps mitigate emissions in these groups, then pursuing more renewable energy or the usage of nuclear energy will have beneficial effects on mitigating $\mathrm{CO}_{2}$ emissions. Specific questions in regards to this study are as follows: first, from the perspective of the whole process, does the consumption of renewable energy and nuclear energy contribute to $\mathrm{CO}_{2}$ emissions reduction? Secondly, if so, which energy source contributes more? Fossil fuels, an important additive variable was included since they are known as the main producer of $\mathrm{CO}_{2}$. Labor is also added as an additional variable, because through economic cooperation, local and foreign industries will hire more workers, which will increase energy consumption in the long run. Since energy consumption is related to $\mathrm{CO}_{2}$ emissions, we consider human capital. Table 1 unveils recent studies that employed the nuclear and renewable energies in different research location.

\section{INSERT TABLE 1}

The remainder of this paper is organized as follows: Section 2 presents data and classification methodology in section 3, section 4 introduces estimation of results and discussion, lastly conclusion and policy recommendation in section 5 . 


\section{Data and classification}

Some countries were omitted in this study as a result of missing data, thus annual data covering 1990-2018 for 40 BRI countries were utilized. The characteristics of the variables in this study are

122 presented in Table 2.

\section{INSERT TABLE 2}

124 Since energy is an important input to production, energy trade is critical to the economic growth 125 of countries whose energy reserves cannot meet their energy needs. Likewise energy cooperation 126 based on free trade is an important part of BRI. Thus due to the lack of conventional energy 127 reserves and increasing reliance on energy imports, it is necessary to divide these countries into 128 energy importers and energy exporters (Table 3). This offers the belt and road initiative a way to 129 diversify energy sources and ensure energy security. The classification is determined based on a 130 ratio of net energy imports to energy usage, where energy imports are defined as energy 131 consumption minus the output expressed in oil equivalent, according to the international energy 132 agency (IEA). Net exporters are countries with negative net energy imports (Liu and Hao 2018).

\section{INSERT TABLE 3}

\section{Methodology}

\subsection{Model specification}

The relationships amidst nuclear energy, renewable energy, labor force, fossil fuels, economic growth and $\mathrm{CO}_{2}$ emissions can be estimated as a function following a similar study done by Saud et al. (2019) and written as;

$$
C \mathrm{O}_{2}=f(G D P, N U C, R E W, L A B, F O S)
$$


142 Equation one can be converted into an econometric model including a constant term $\left(\beta_{0}\right)$ and an

143 error term $\left(\varepsilon_{i t}\right)$ as in Eq. (2):

$$
C O_{2 i t}=\beta_{0}+\beta_{1} G D P_{i t}+\beta_{2} N U C_{i t}+\beta_{3} R E W_{i t}+\beta_{4} L A B_{i t}+\beta_{5} F O S_{i t}+\varepsilon_{i t}
$$

where $i=1,2,3, \ldots N$ indicating each panel country; $t=1,2,3 \ldots N$ indicating the time span, $\beta_{0}$ is the intercept term and $\varepsilon_{i t}$ is the error term. The parameters $\beta_{1}-\beta_{5}$ indicate the unknown coefficients of GDP, NUC. REW, LAB, FOS respectively. In order to better fit the estimation, natural logarithmic transformation is taken.

\subsection{Econometric approach}

\subsubsection{Cross sectional dependence (CSD)}

With the increasing degree of economic integration, interdependence between countries is often strong. Ignoring cross sectional effects in estimation of panel data may therefore lead to deviation in estimation and error in prediction. When $T>N$, the Lagrange multiplier (LM) test developed (Breusch and Pagan 1980) can be employed. On the other hand, when $T<N$, which is the most common case in panels, the LM test statistics have no satisfactory statistical properties because they show a large amount of dimensional distortion (De Hoyos and Sarafidis 2006). Thus, before analyzing the stationary properties of variables, we used three different tests, the Pesaran CD test, the Friedman test, and the free test, to verify whether the panel data had cross-sectional correlations (De Hoyos and Sarafidis 2006).

The Pesaran CD test also can be computed as:

$$
C D=\sqrt{\frac{2}{N(N-1)}} \sum_{i=1}^{N-1} \sum_{j=i+1}^{N} T_{i j} \hat{\rho}_{i j}^{2} \rightarrow N(0,1)
$$

Where $\rho_{i j}$ is the coofficients of correlation obtained from the residuals; 
The Friedman's test can be calculated by;

$$
R_{\text {ave }}=\frac{2}{N(N-1)} \sum_{i=1}^{N-1} \sum_{j=i+1}^{N} \hat{r}_{i j}
$$

166

Where $\hat{r}_{i j}$ is the sample estimate of the rank correlation coefficient of the residuals. The $C D$ and

$R_{\text {ave }}$ share a mutual characteristics; they involve the sum of the correlation coefficients of the

170 residual matrix, not the sum of the correlation squared used in the $L M$ test. The free's test can also

171 be computed as;

$$
R_{a v e}^{2}=\frac{2}{N(N-1)} \sum_{i=1}^{N-1} \sum_{j=i+1}^{N} \hat{r}_{i j}^{2}
$$

172

174 Where $R_{\text {ave }}^{2}$ been the sample estimate of the rank correlation coefficient of the residuals squared.

177 considers CSD must be taking into account to obtain reliable estimates. In responds to this, a second generation panel root test such as Pesaran (2007) cross-sectionally dependent augmented 179 dickey fuller (CADF) test was adopted. The regression for this test is given as:

$$
\Delta y_{i t}=\alpha_{i}+\beta_{i} y_{i t-1}+\theta_{i} \bar{y}_{t-1}+\sum_{j=1}^{\rho} \gamma_{i j} \Delta y_{i t-1}+\sum_{j=0}^{\rho} \delta_{i j} \Delta \bar{y}_{t-j}+d_{i t}+\varepsilon_{i t}
$$

182 Where $\bar{y}_{t}=\frac{1}{N} \sum_{i=1}^{N} y_{i t}$ and it is included in the equation as a proxy for the effects for unobserved 183 common factor. $\alpha_{i}$ is time invariant individual nuisance parameter, $\beta_{i}, \theta_{i}, \gamma_{i j}$ and $\delta_{i j}$ respectively 
represent individual-specific effect, individual-specific linear trend and common time effect. After running the CADF statistic, which similar to the IPS statistic of Im et al. (2003), it is computed as

$$
\operatorname{CIPS}(N, T)=\frac{1}{N} \sum_{i=1}^{N} t_{i}(N, T)
$$

Where $t_{i}(N, T)$ is the value of $\beta_{i}$ in equation 7. $\bar{y}_{t}$ inclusion in the unit root equation, makes the test statistic inconsistent with the ADF statistics, so Peseran provide the critical values.

\subsubsection{Westerlund-Edgerton Cointegration test}

The Westerlund-Edgerton bootstrap panel cointegration test was employed in estimating the long run effects of the parameters. They proposed two panel cointegration tests for the null hypothesis without cointegration, taking into account structural break in the intercept and slope of the cointegration regression. This test not only provides good results, but also applies to all situations where CSD exists or does not exist. Westerlund and Edgerton (2007) hinted four residual test statistics to evaluate the null hypothesis without cointegration. Two of the tests are group statistics, and the other two are panel statistics, which are normally distributed. In essence, this test measure the existence of cointegration by judging whether there is error correction in a single panel group and the whole panel. The model was built on:

$$
y_{i t}=\delta_{0 i}+\delta_{1 i t}+n_{i} D_{i t}+x^{\prime}{ }_{i t} \beta_{i}+\left(D_{i t} x_{i t}\right)^{\prime} \gamma_{i}+z_{i t}
$$

Where $\mathrm{i}=1 \ldots \ldots \mathrm{N}, \mathrm{t}=1 \ldots \ldots \mathrm{T}, \mathrm{x}_{\mathrm{it}}=\mathrm{x}_{\mathrm{i}, \mathrm{t}-1}+\mathrm{v}_{\mathrm{it}}$ is $\mathrm{k}$-dimensional vector, I(1). Dummy variables is $D_{i t} . D_{i t}=1$ if $t>T_{i}^{b}$ and otherwise zero. $T_{i}^{b}$ corresponds to the break date for individual i such that $\mathrm{T}_{\mathrm{i}}^{\mathrm{b}}=\theta_{\mathrm{i}}^{\mathrm{b}}$ with $\theta_{\mathrm{i}}^{\mathrm{b}} \in(\Psi, 1-\Psi)$ and $\Psi \in(0,1), \delta_{0 \mathrm{i}}$ and $\mathrm{n}_{\mathrm{i}}$ are unknown coefficient vectors and $z_{i t}$ is the residual term. $z_{i t}$ is then develop as;

$$
\vartheta_{i}(L) \Delta e_{i t}=\vartheta_{i} e_{i . t-1}+\varepsilon_{i t}
$$


209 With $\vartheta_{\mathrm{i}}(\mathrm{L})=1-\sum_{\mathrm{j}=1}^{\mathrm{pi}} \vartheta_{\mathrm{ij}} \mathrm{L}^{\mathrm{j}}$ being a scalar lag polynomial and $\varepsilon_{\mathrm{it}}$ is the error process.

$210 \mathrm{H}_{0}=\vartheta_{\mathrm{i}}=0$ No existence of cointegration for $\forall_{\mathrm{i}}$

$211 \mathrm{H}_{1}=\vartheta_{\mathrm{i}}<0$ Existence of cointegration for $\forall_{\mathrm{i}}$

212 In panel testing, the alternate hypothesis means that the adjustment to equilibrium is uniform across

213 different populations. Therefore, rejecting the null hypothesis means the existence of cointegration

214 in the various groups.

$215 \mathrm{H}_{0}=\vartheta_{\mathrm{i}}=0$ No existence of cointegration for $\forall_{\mathrm{i}}$

$216 \mathrm{H}_{1}=\vartheta_{\mathrm{i}}<0$ Existence of cointegration for $\forall_{\mathrm{i}}$

217 In addition, the alternative hypothesis means that the adjustment for equilibrium among different 218 groups is heterogeneous, and the refusal of the null hypothesis means there is an indication of 219 cointegration among group member. Where $\hat{a}_{\hat{a}}$ is the standard error of $\hat{a}_{i}$, such that both the 220 statistics diverged to negative infinity, indicating the test decisions were done based on the left tail 221 of the standard normal distribution such that ;

$$
\hat{a}=\left(\sum_{i=1}^{N} \sum_{t=2}^{T} \tilde{y}_{i, t-1}\right)^{-1} \sum_{i=1}^{N} \sum_{t=2}^{T} \frac{1}{\hat{a}_{i}} \tilde{y}_{i, t-1} \Delta \tilde{y}_{i t}
$$

$$
\hat{a}_{\hat{a}}=\left[\left(\frac{1}{N} \sum_{i=1}^{N}\left(\frac{\hat{a}_{i}}{\hat{a}_{i}(1)}\right)^{2}\right)^{-1} \sum_{i=1}^{N} \sum_{t=2}^{T} \tilde{y}_{i, t-1}^{2}\right]^{-1 / 2}
$$

\subsubsection{The pooled mean group estimator (PMG)}

227 In estimating the short and long run estimates for the variables, the pooled mean group was employed. PMG allowed the short-term parameters to be different between groups and the longterm coefficients to be equal between groups. Pooled mean group (PMG) was developed by 
231 variances between groups are heterogeneous, while the long-term slope coefficient between groups

232 is uniform. The ARDL model of late has been employed because it can be used in situations where

233 the sequence is $\mathrm{I}(1)$ or $\mathrm{I}(0)$, as well as to obtain both short and long run estimates. Finally, the

234 Hausman poolability test, was performed to determine whether pooling long-term coefficients

235 were appropriate and effective. Observing an $\operatorname{ARDL}(\mathrm{p}, \mathrm{q})$ model as an example, where the lag

236 order is $\mathrm{p}$ of the response variable and the lag order of the explanatory variables is given by q. The

237 model can be expressed as;

$$
y_{i t}=\sum_{j=1}^{p} \lambda_{i j} y_{i . t-j}+\sum_{j=1}^{q} \delta_{i j}^{\prime} x_{i . t-j}+\varepsilon_{i, t}
$$

$y_{i t}$ indicates the response variable, $x_{i . t-j}$ represents $k-1$ vector of explonatory variables, $\delta_{i j}^{\prime}$ is a the error terms, $i=1,2, \ldots \ldots N$ stands for the individual countries and, $t=1,2, \ldots T$ is the periods. The error correction model of equation (15) under the equilibrium state is expressed as;

$$
\Delta y_{i . t}=\phi_{i} y_{i . t}+\alpha_{i}^{\prime} x_{i t}+\sum_{j=0}^{m-1} \lambda_{i j}^{*} \Delta y_{i . t-j}+\sum_{j=0}^{m-1} \delta_{i j}^{*^{\prime}} \Delta x_{i . t-j}+\varepsilon_{i . t}
$$

$$
\phi_{i}=-1+\sum_{j=1}^{m} \lambda_{i j} ; \alpha_{i}=\sum_{j=1}^{n} \delta_{i j} ; \lambda_{i j}^{*}=\sum_{j=1}^{n} \lambda_{i p}+, j=1,2, \ldots m-1
$$

By regrouping equation (16) can be summarized as

$$
\Delta y_{i . t}=\phi_{i}\left(y_{i . t}+\theta_{i}^{\prime} x_{i t}\right)+\sum_{j=0}^{m-1} \lambda_{i j} \Delta y_{i . t-j}+\sum_{j=0}^{m-1} \delta_{i j}^{*^{\prime}} \Delta x_{i . t-j}+\varepsilon_{i . t}
$$


253

254

255

256

257

258

259

260

261

262

264

265

266

263

268

269

270

267

272

273

274

271

$\theta_{i}$ interprets the long run association amongst the response $\left(y_{i . t}\right)$ and exploratory variables $\left(x_{i t}\right)$ whilst, $\delta_{i j}^{*}$ show parameters in the short run. The short-term causalities from the explanatory variables to the dependent variables are describe by the short-run parameters. $\delta_{i j}$ 's on the other hand indicates coefficients in the long-term which are concerned with the long-term causalities between the dependent variables and their corresponding explanatory variables. $\phi^{\prime} s$ indicates the error correction terms . They are expected to be negative and significant, indicating long term relationship among the variables. The rate of adjustment is calculated according to the inverse ratio of the absolute value of the error correction terms. Hence we constructed the modified model in equation (2) as ARDL model in the following format;

$$
\begin{aligned}
\Delta C O_{2 i . t}=\beta_{0}+ & \phi_{1, i}\left[C O_{2 i, t-1}-\theta_{1 . i}^{\prime}\left(C O_{2.1 i . t}+G D P_{2 i . t}+R E W_{3 i . t}+N U C_{4 i . t}+L A B_{5 i . t}+F O S_{6 i . t}\right)\right] \\
& +\sum_{j=0}^{m-1} \delta_{i j}^{*^{\prime}} \Delta C O_{21 i, t-j}+\sum_{j=0}^{m-1} \delta_{i j}^{*^{\prime}} \Delta G D P_{2 i, t-j}+\sum_{j=0}^{m-1} \delta_{i j}^{*^{\prime}} \Delta R E W_{3 i, t-j}+\sum_{j=0}^{\sum_{j-0}} \delta_{i j}^{*^{\prime}} \Delta N U C_{4 i, t-j} \\
& +\sum_{j=0}^{m-1} \delta_{i j}^{*^{\prime}} \Delta L A B_{5 i, t-j}+\sum_{j=0}^{m-1} \delta_{i j}^{*^{\prime}} \Delta F O S_{6 i, t-j}+\varepsilon_{i . t}
\end{aligned}
$$

$$
\begin{aligned}
\Delta G D P=\beta_{0}+ & \phi_{1, i}\left[G D P_{i, t-1}-\theta_{1 . i}^{\prime}\left(C O_{2.1 i . t}+G D P_{2 i . t}+R E W_{3 i . t}+N U C_{4 i . t}+L A B_{5 i . t}\right.\right. \\
& \left.\left.+F O S_{6 i . t}\right)\right]+\sum_{j=0}^{m-1} \delta_{i j}^{*^{\prime}} \Delta C O_{2.1 i, t-j}+\sum_{j=0}^{m-1} \delta_{i j}^{*^{\prime}} \Delta G D P_{2 i, t-j}+\sum_{j=0}^{m-1} \delta_{i j}^{*^{\prime}} \Delta R E W_{3 i, t-j} \\
& +\sum_{j=0}^{m-1} \delta_{i j}^{*^{\prime}} \Delta N U C_{4 i, t-j}+\sum_{j=0}^{m-1} \delta_{i j}^{*^{\prime}} \Delta L A B_{5 i, t-j}+\sum_{j=0}^{m-1} \delta_{i j}^{*^{\prime}} \Delta F O S_{6 i, t-j}+\varepsilon_{i . t}
\end{aligned}
$$

$$
\begin{aligned}
& \Delta R E W_{i . t}=\beta_{0}+\phi_{1, i}\left[R E W_{i, t-1}-\theta_{1 . i}^{\prime}\left(C O_{2.1 i . t}+G D P_{2 i . t}+R E W_{3 i . t}+N U C_{4 i . t}+L A B_{5 i . t}+F O S_{6 i . t}\right)\right] \\
& +\sum_{\substack{j=0 \\
m-1}}^{m-1} \delta_{i j}^{*^{\prime}} \Delta C O_{2.1 i, t-j}+\sum_{\substack{j=0 \\
m-1}}^{m-1} \delta_{i j}^{*^{\prime}} \Delta G D P_{2 i, t-j}+\sum_{j=0}^{m-1} \delta_{i j}^{*^{\prime}} \Delta R E W_{3 i, t-j}+\sum_{j=0}^{m-1} \delta_{i j}^{*^{\prime}} \Delta N U C \\
& +\sum_{j=0}^{m} \delta_{i j}^{*^{\prime}} \Delta L A B_{5 i, t-j}+\sum_{j=0}^{m-1} \delta_{i j}^{*^{\prime}} \Delta F O S_{6 i, t-j}+\varepsilon_{i . t}
\end{aligned}
$$




$$
\begin{aligned}
\Delta N U C_{i . t}=\beta_{0}+ & \phi_{1, i}\left[N U C_{i, t-1}-\theta_{1 . i}^{\prime}\left(C O_{2.1 i . t}+G D P_{2 i . t}+R E W_{3 i . t}+N U C_{4 i . t}+L A B_{5 i . t}+F O S_{6 i . t}\right)\right] \\
& +\sum_{j=0}^{m-1} \delta_{i j}^{*^{\prime}} \Delta C O_{2.1 i, t-j}+\sum_{j=0}^{m-1} \delta_{i j}^{*^{\prime}} \Delta G D P_{2 i, t-j}+\sum_{j=0}^{m-1} \delta_{i j}^{*^{\prime}} \Delta R E W_{3 i, t-j} \\
& +\sum_{j=0}^{m-1} \delta_{i j}^{*^{\prime}} \Delta N U C_{4 i, t-j}+\sum_{j=0}^{m-1} \delta_{i j}^{*^{\prime}} \Delta L A B_{5 i, t-j}+\sum_{j=0}^{m-1} \delta_{i j}^{*^{\prime}} \Delta F O S_{6 i, t-j}+\varepsilon_{i . t}
\end{aligned}
$$

$$
\begin{aligned}
\Delta L A B_{i . t}=\beta_{0}+ & \phi_{1, i}\left[L A B_{i, t-1}-\theta_{1 . i}^{\prime}\left(C O_{2.1 i . t}+G D P_{2 i . t}+R E W_{3 i . t}+N U C+L A B_{5 i . t}+F O S_{6 i . t}\right)\right] \\
& +\sum_{j=0}^{m-1} \delta_{i j}^{*^{\prime}} \Delta C O_{2.1 i, t-j}+\sum_{j=0}^{m-1} \delta_{i j}^{*^{\prime}} \Delta G D P_{2 i, t-j}+\sum_{j=0}^{m-1} \delta_{i j}^{*^{\prime}} \Delta R E W_{3 i, t-j} \\
& +\sum_{j=0}^{m-1} \delta_{i j}^{*^{\prime}} \Delta N U C_{4 i, t-j}+\sum_{j=0}^{m-1} \delta_{i j}^{*^{\prime}} \Delta L A B_{5 i, t-j}+\sum_{j=0}^{m-1} \delta_{i j}^{*^{\prime}} \Delta F O S_{6 i, t-j}+\varepsilon_{i . t}
\end{aligned}
$$

$$
\begin{aligned}
& \Delta E N R_{i . t}=\beta_{0}+\phi_{1, i}\left[E N R_{i, t-1}-\theta_{1 . i}^{\prime}\left(C O_{2.1 i . t}+G D P_{2 i . t}+R E W_{3 i . t}+N U C_{4 i . t}+L A B_{5 i . t}+F O S_{6 i . t}\right)\right] \\
& +\sum_{\substack{j=0 \\
m-1}}^{m-1} \delta_{i j}^{*^{\prime}} \Delta C O_{2.1 i, t-j}+\sum_{j=0}^{m-1} \delta_{i j}^{*^{\prime}} \Delta G D P_{2 i, t-j}+\sum_{\substack{j=0 \\
m-1}}^{m-1} \delta_{i j}^{*^{\prime}} \Delta R E W_{3 i, t-j} \\
& +\sum_{j=0}^{m-1} \delta_{i j}^{*^{\prime}} \Delta N U C_{4 i, t-j}+\sum_{j=0}^{m-1} \delta_{i j}^{*^{\prime}} \Delta L A B_{5 i, t-j}+\sum_{j=0}^{m-1} \delta_{i j}^{*^{\prime}} \Delta F O S_{6 i, t-j}+\varepsilon_{i . t}
\end{aligned}
$$

Equation (15) together with equation (16), (17), (18) (19) and (20) will be estimated utilizing the PMG estimator.

\subsubsection{PVECM granger causality test}

In order to check the validity of the PMG estimation was tested using panel vector error correction technique (PVECM) granger causality. If there is evidence of cointegration among the variables, then the relationship among the variables can be modelled with VECM, which can be used to reveal the direction of granger causality between variable pairs. VECM can also be used to detect the short-term and long-term relationships between variables and can identify the source of causality. When there is no long-term relationship, the auto regression (AR) model is used. For 
the latter, it estimates only short-term causalities. This study employed the former granger causality method because cointegration results suggested a long-term relationship among the variables selected. The PVECM can be showed as;

$$
\left[\begin{array}{l}
\Delta C O_{2 . i t} \\
\Delta g d p_{i t} \\
\Delta n u c_{i t} \\
\Delta r e w_{i t} \\
\Delta l a b_{i t} \\
\Delta \text { fos }_{i t}
\end{array}\right]=\left[\begin{array}{l}
\delta_{1} \\
\delta_{2} \\
\delta_{3} \\
\delta_{4} \\
\delta_{5} \\
\delta_{6}
\end{array}\right]+\sum_{j=1}^{k}\left[\begin{array}{llllll}
\beta_{11, j} & \beta_{12, j} & \beta_{13, j} & \beta_{14, j} & \beta_{15, j} & \beta_{16, j} \\
\beta_{21, j} & \beta_{22, j} & \beta_{23, j} & \beta_{24, j} & \beta_{25, j} & \beta_{26, j} \\
\beta_{31, j} & \beta_{32, j} & \beta_{33, j} & \beta_{34, j} & \beta_{35, j} & \beta_{36, j} \\
\beta_{41, j} & \beta_{42, j} & \beta_{43, j} & \beta_{44, j} & \beta_{45, j} & \beta_{46, j} \\
\beta_{51, j} & \beta_{52, j} & \beta_{53, j} & \beta_{54, j} & \beta_{55, j} & \beta_{56, j} \\
\beta_{61, j} & \beta_{62, j} & \beta_{63, j} & \beta_{64, j} & \beta_{65, j} & \beta_{66, j}
\end{array}\right] \times\left[\begin{array}{l}
\Delta e m s_{i t-1} \\
\Delta g d p_{i t-1} \\
\Delta n u c_{i t-1} \\
\Delta r e w_{i t-1} \\
\Delta l a b_{i t-1} \\
\Delta \text { fos }_{i t-1}
\end{array}\right]+\left[\begin{array}{l}
\mu_{1 i t} \\
\mu_{2 i t} \\
\mu_{3 i t} \\
\mu_{4 i t} \\
\mu_{5 i t} \\
\mu_{6 i t}
\end{array}\right]
$$

Where $\Delta$ is the first difference operator, $\delta_{i}$ indicate heterogeneity parameter, $\mathrm{ECT}_{\mathrm{it}-1}$ is the lagged error correction term, $j$ represents the lag length and $\mu$ indicate the random error term.

\section{Estimation results and discussion}

\subsection{Descriptive statistics}

All variables are transformed into natural logarithm form to interpret coefficients into elasticities, the time frame were due to the data available. Table 4 reveals the descriptive statistics of 40 countries along the Belt and Road from 1990 to 2018. For the sampled of BRI countries, $\mathrm{CO}_{2}(\mathrm{M}=4.720, \mathrm{SD}=3.926), \mathrm{GDP}(\mathrm{M}=7.786, \mathrm{SD}=1.331), \mathrm{LAB}(\mathrm{M}=15.890, \mathrm{SD}=$ $1.685)$, NUC $(M=7.522, \mathrm{SD}=2.198)$, FOS $(\mathrm{M}=7.208, \mathrm{SD}=0.909)$ and $\mathrm{REW}(\mathrm{M}=$ $2.761, \mathrm{SD}=0.909)$. Comparing the descriptive for the two groups, table 3 revealed that $\mathrm{CO}_{2}$ in energy exporters $(M=2.129, S D=1.073)$ to importers countries $(M=5.125, S D=3.985)$. For GDP, energy importers $(M=7.911, S D=1.307)$ to energy exporters $(M=6.981, S D=1.307)$.

LAB has $(M=17.182, S D=0.787)$ compared to energy importers $(M=15.688, S D=1.698)$. In regards to NUC, energy importers $(M=5.421, S D=0.261)$ compared to energy exporters $(M=6.774, S D=1.387)$. For REW energy exporters $(M=3.192, S D=1.387)$ compared to 
$320(\mathrm{M}=2.693, \mathrm{SD}=0.619)$ in energy importers countries. Lastly comparing FOS, energy importers

$(\mathrm{M}=7.319, \mathrm{SD}=0.886)$ to energy exporters $(\mathrm{M}=6.498, \mathrm{SD}=0.718)$.

In general, for normal distribution using kurtosis and skewness, the normal value of skewness and kurtosis is "3" and "0" respectively. Table 4 revealed that using skewness and kurtosis, none

324 of the observed variables were normally distributed. $\mathrm{CO}_{2}$ in all the panel groups indicates that, it

325 is flattering to the right. It peakness in the main panel and energy exporters show a mesokurtic

326 distribution (value of kurtosis approximately 3) whereas in energy importers we have platykurtic

327 distribution (value of kurtosis below 3). Skewness in GDP is approximately 0 for the main panel

328 as well in energy importers panel but in energy exporters, it is negatively skewed. For kurtosis, all

329 the panel groups indicates platykurtic distribution (value of kurtosis below 3). LAB from table 4

330 show that for all panel group, it is skewed to the right, while for kurtosis, the main panel and energy

331 importers are leptokurtic (value of kurtosis greater than 3) while that of energy exporters are

332 platykurtic (value of kurtosis less than 3). For NUC, the skewness value indicates that all panel

333 groups are flattering to the right, while for kurtosis, the main panel and energy exporters indicate

334 a leptokurtic distribution while energy importers show a platykurtic distribution. REW in all panel

335 groups show that a negative skweness, indicating REW in all group as flattering to the left. Kurtosis

336 in both the main panel and energy importers indicate a leptokurtic distribution while energy

337 exporters show a platykurtic distribution. Lastly for FOS, the main and energy importers panel

338 indicate that FOS is skewed to the left while in energy exporters panel, FOS is skewed to the right.

339 For kurtosis, all panel group indicate a platykurtic distribution for FOS. 
The Pearson product moment correlation results among the variables is revealed in table 5 .

$343 \mathrm{CO}_{2}$ is positive and significantly correlated with GDP, NUC, and FOS but negatively and

344 statistically significantly correlated with LAB and REW. GDP was identified to be positively and

345 significantly related with NUC and FOS but negatively and significantly associated with LAB and

346 REW. It was also evidenced that a negative and significant correlation was linked from LAB to

347 NUC and FOS but positively and significantly correlated with REW. While NUC is positively

348 and significantly related with REW and FOS. Lastly it was evidenced that a negative link was

349 found between REW and FOS. Pearson product difference correlation, is calculated by the 350 formula;

$$
r=\frac{\sum_{i=1}^{n}\left(x_{1 i}-\hat{x}_{1}\right)\left(x_{2 i}-\hat{x}_{2}\right)}{\sqrt{\sum_{i=1}^{n}\left(x_{1 i}-\hat{x}_{1}\right)^{2}} \sqrt{\sum_{i=1}^{n}\left(x_{2 i}-\hat{x}_{2}\right)^{2}}}
$$

351

352

where $\hat{x}$ is the sample mean value

FOS), the Variance Inflation Factor (VIF) together with Tolerance for each variable is calculated.

357 Table 6 indicates no presence of multicolinearity among the independent variables because the

358 VIF values are far less than 5 and Tolerance values are not less than 0.2 (Thompson et al. 2017).

359 This implies that, the variables (GDP, LAB, NUC, REW, and FOS), independently have impact 360 on $\mathrm{CO}_{2}$ emissions. 


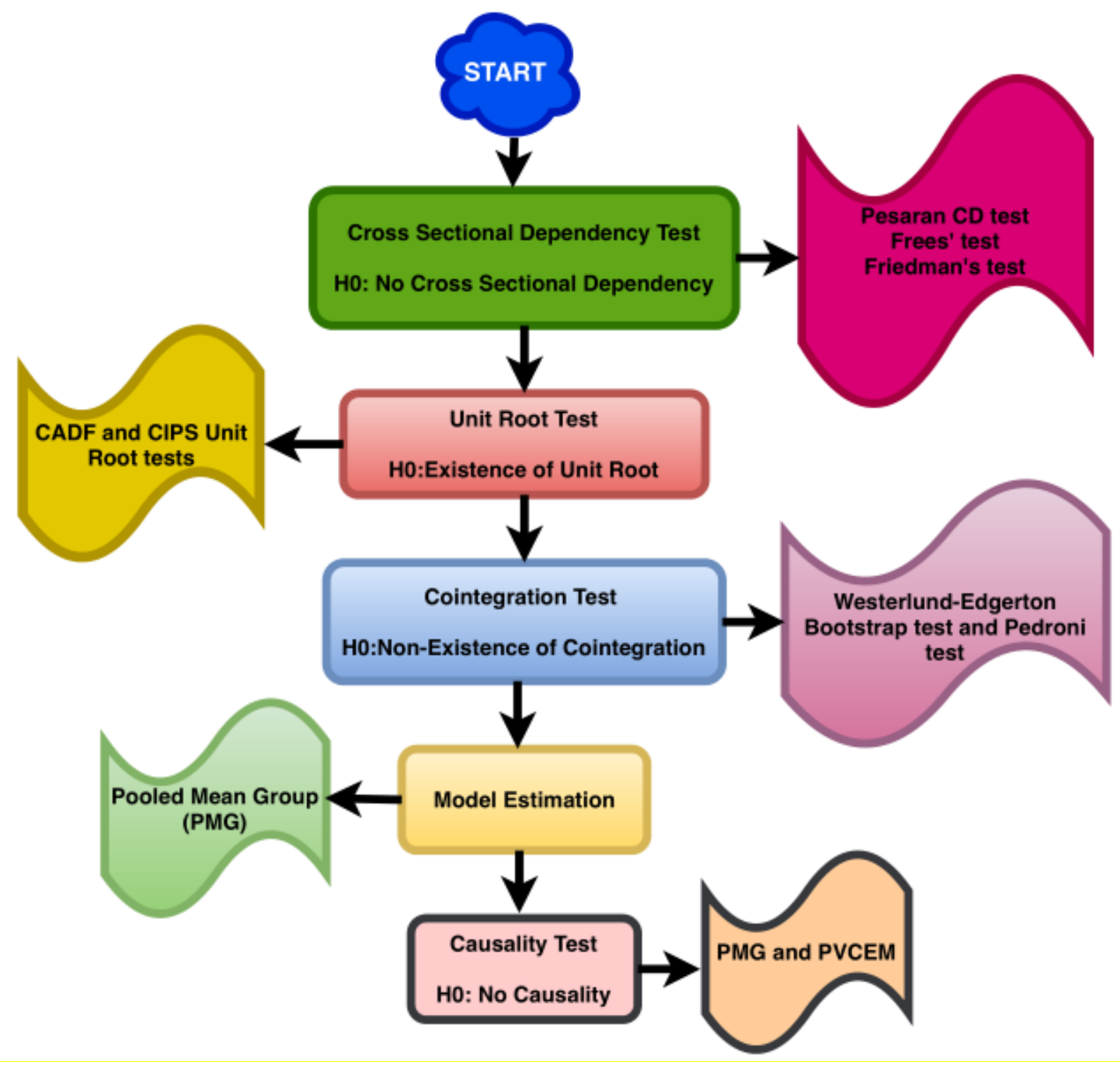

Figure 1: Graphical representation of the econometric approach.

\subsection{Cross sectional independence test}

Table 7 provides the results for cross sectional dependence test. The Pesaran CD test rejects

367 the null hypothesis of no cross-sectional dependence. But a possible drawback of CD test is the

368 possibility of adding positive and negative correlations which may lead to acceptance of the

369 alternate hypothesis, even if there are enough evidence of cross-sectional correlation in the error

370 terms. Therefore the mean absolute correlation of the residuals is used to make the decision. 
371 Therefore from the results of the Pesaran CD test, frees' and Friedman's test the null of cross-

372 sectional independence was rejected and concluded that cross sectional correlation exist among

373 the panels in this study. This results is consistent with work done by Wang and Dong (2019), who

374 also identified cross sectional independence in 14 Sub-Saharan African countries. Likewise that

375 of the work by Chen et al. (2020) in OECD countries.

INSERT TABLE 7

377

378

379

380

381

382

383

384

\subsection{Panel unit root test}

Table 8 indicates the results obtained from the Pesaran CADF and Pesaran CIPS panel unit root tests. The results show that the null hypothesis of unit root cannot be rejected at levels of the variables, whether the time trend is included or not. However after the first difference, the six variables were stable at significant levels of $1 \%, 5 \%$, and $10 \%$. Therefore, all variables in this study were of order $0, \mathrm{I}(0)$, then turned to an integral of order 1 , that is, I(1). Estimating nonstationary variables in econometrics is potentially generating spurious results. Thus before estimation, the stationarity of the variables was ascertained. The stationarity of the employed variables are in line with the work done by Haseeb et al. (2018) in BRICS countries while studying the relationship between financial development, globalization and $\mathrm{CO}_{2}$ emissions.

\section{INSERT TABLE 8}

\subsection{Panel cointegtarion test}

Having confirmed that the series in our panel data set are cross sectionally dependent and are integrated of order one, Westerlund and Edgerton (2007) cointegration test, was used to establish their long run association. For comparative analysis, Pedroni (2004) cointegration test was also employed. The results from long run test are revealed in Table 9 and table 10. The null hypothesis of no cointegration is vehemently rejected at various significant level with respect to the statistics $G_{\tau}, G_{\alpha}, P_{\tau}$ and $P_{\alpha}$. Our argument was centered by the robust p-value, which present a robust proof 
395 of the cointegration within variables as shown in table 9. For pedroni's panel cointegration test,

396 Table 10 reports a total of seven tests, by a majority decision with four tests the null hypothesis of 397 no cointegration was rejected and concluded that there is enough evidence of cointegration among 398 variables in the panel data set. The long run association among the variables are in coherent with 399 the work done by Khattak et al. (2020) in BRICS countries but does not aligned with the study 400 Acaravci and Ozturk (2010) who for 15 interim countries fail to establish a long term affiliation 401 between energy usage and economic growth.

402

403

404

405

406

407

408

409

410

411

412

413

414

415

416

417

418

INSERT TABLE 9

INSERT TABLE 10

\subsection{Parameter estimations}

Having infer cointegration among the variables, it was necessary to determine estimates for the short-term and long-term and again analyze the causalities. To be able to employ the best estimator, hausman test was used as required by literature to determine the proper estimator for the model. The hausman test was used to confirm the hypothesis of long-term homogeneity, hence it was reasoned that PMG estimator was more effective. According to the results from the PMG estimator, estimate of error correction terms of all variables (ECTs) have expected signs indicating statistically significant at the $1 \%$ level.

\subsubsection{Pooled Mean Group (PMG) for the sampled BRI countries}

Estimations in regards to Equation (15-20), considering the variables under study are revealed in Table 11. At $1 \%$ increase in GDP, LAB, NUC, REW, and FOS, the variables GDP, NUC and FOS have a positive and significant impact on $\mathrm{CO}_{2}$, however the variables REW has negative and significant impact on $\mathrm{CO}_{2}$. This indicates that GDP, NUC and FOS increase $\mathrm{CO}_{2}$ by $0.890 \%$, $0.134 \%$ and $0.701 \%$ respectively, while REW reduce $\mathrm{CO}_{2}$ by $0.416 \%$. However labor force has no significant impact on $\mathrm{CO}_{2}$ considering the main panel for the sampled BRI countries. In regards 
419 to the $\mathrm{CO}_{2}$-GDP relationship, a positively significant one way causal connection was found from

420 GDP to $\mathrm{CO}_{2}$ in both the short and long run. A positively significant two way bidirectional link was

421 depicted between FOS and $\mathrm{CO}_{2}$ in the short and long run, this results is in line with work done by

422 Sasana and Ghozali (2017) in BRICS countries. A negatively significant causal link was revealed

423 from $\mathrm{REW}$ to $\mathrm{CO}_{2}$ in the long run but none was depicted in the short run. The outcome is in

424 resonance with the study done by Apergis and Payne (2015) in south America. A one way

425 positively and significant causal links was found from $\mathrm{NUC}$ and $\mathrm{CO}_{2}$ in the long run, similarly in

426 the short run, a one way link from NUC to $\mathrm{CO}_{2}$ was felt. This results is similar to the study done

427 by Al-Mulali (2014) in 30 major nuclear energy consuming countries.

428 In regards to these energies and economic growth relationship, GDP has a positive and 429 significant bidirectional causal relationship with FOS, REW and NUC in the long run. The 430 outcome between REW and GDP is in line with the study done by Kahia et al. (2017) in 11 MENA 431 net oil importing countries. However in the short run, GDP has a two way causal link with FOS 432 while a one way causal link was presented from NUC and REW to GDP. The link between GDP 433 and NUC with REW is in line with work done (Ohler and Fetters 2014); Saidi and Mbarek (2016) 434 in 20 OECD and nine developed countries respectively. The addition of labor force is an important 435 contribution of this study to ease the bias related to the missing variables. The estimation from 436 PMG results point that, the variables $\mathrm{CO}_{2}$ emissions $\left(\mathrm{CO}_{2}\right)$, economic growth (real GDP), nuclear 437 energy (NUC), renewable energy (REW) and fossil fuel (FOS) are very significant, the rates of 438 adjustment correspondingly is given by $5.38,1.16,1.23,3.04$ and 4.95 years respectively, hence 439 the long term equilibrium show that the variables deviation response quickly. Table 11 as well 440 confirms that the use of REW are beneficial to the countries along the BRI because it reduces $\mathrm{CO}_{2}$ 441 emissions while it increases GDP. However the use of fossil fuel and NUC increase GDP but 
442 reduces the quality of the environment in the long run. The same occurs in the short run with 443 exception of NUC which reduces GDP.

452 felt from GDP to $\mathrm{CO}_{2}$ in the long run while a two way causal association was depicted in the short 453 run for $\mathrm{CO}_{2}$-GDP relationship. Considering energies consumption and $\mathrm{CO}_{2}$ emissions, a positively 454 significant two way association was depicted between $\mathrm{CO}_{2}$ and $\mathrm{FOS}$ and with NUC in the long run 455 but a negatively significant unidirectional causal link was seen from REW to $\mathrm{CO}_{2}$. However in the 456 short run, a positively two way causal effect was depicted between FOS and $\mathrm{CO}_{2}$ while a negatively 457 significant association was seen from REW to $\mathrm{CO}_{2}$ in the short run. In the short run no causal 458 effect was felt between NUC and $\mathrm{CO}_{2}$. Similar results was depicted by Saidi and Mbarek (2016) 459 in their research in nine developed countries.

460 Considering energies consumption and economic growth, in the long run all three energy 461 consumptions have a positively and significant bidirectional association with GDP. Nevertheless 462 in the short run, FOS and REW have positive and significant two way association with GDP but 463 NUC has no significant impact with GDP. The variables $\mathrm{CO}_{2}$, economic growth (real GDP), 464 nuclear energy (NUC), renewable energy (REW) and fossil fuels (FOS) are all significant, 
corresponding to the adjustment rates $8.771,3.788,4.717,2.985$ and 4.878 years respectively, indicating that each variable reacts rapidly to deviances equilibrium in long-term.

\section{INSERT TABLE 12}

\subsubsection{Pooled Mean Group (PMG) results for energy exporters countries}

Parameter estimations in regards to Equation (15-20), considering the variables under study are revealed in Table 13. The results depict that one percent increase in GDP, LAB, NUC, REW and FOS decrease $\mathrm{CO}_{2}$ by $0.473 \%$ and $0.528 \%$ for NUC and REW respectively. However, an increase of $0.264 \%$ and $0.518 \%$ by GDP and FOS respectively is felt by $\mathrm{CO}_{2}$ emissions. Considering energies consumption and $\mathrm{CO}_{2}$ emissions associations, a positively significant bidirectional association was seen between $\mathrm{FOS}$ and $\mathrm{CO}_{2}$ in the long run but a negatively one way causal effect was depicted from NUC and REW to $\mathrm{CO}_{2}$ also in the long run. The results is in line with the study done Dong et al. (2017) in BRICS countries. Likewise in the short run, a negatively and significant one way causal effect was depicted from REW and NUC to $\mathrm{CO}_{2}$ but a one way causal association from $\mathrm{CO}_{2}$ to FOS was felt as well.

Considering economic growth and energies consumption associations, a positive significant two way association was depicted between GDP with FOS and REW in the long run. However in the long run, a negatively significant one way link was found from NUC to GDP. Likewise, a two way causal links amidst GDP with REW in the short run as the finding of Shahbaz et al. (2015) in their work in Africa, while a unidirectional relationship was depicted from FOS and NUC to GDP. A positively and statistically significant link amidst $\mathrm{CO}_{2}$ and GDP in the long run while in the short run, a negative and significant link was seen from GDP to $\mathrm{CO}_{2}$. The estimation results designate that, the variables $\mathrm{CO}_{2}$ emissions $\left(\mathrm{CO}_{2}\right)$, economic growth (real GDP), nuclear energy (NUC), renewable energy (REW) and fossil fuels (FOS) are extremely significant, corresponding to the 

the causalities depicted during the PMG estimation.

INSERT TABLE 13

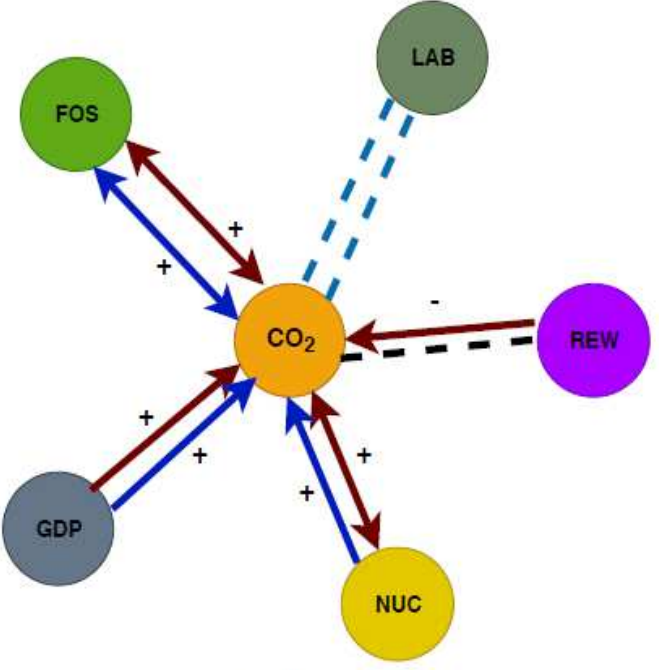

BRI COUNTRIES

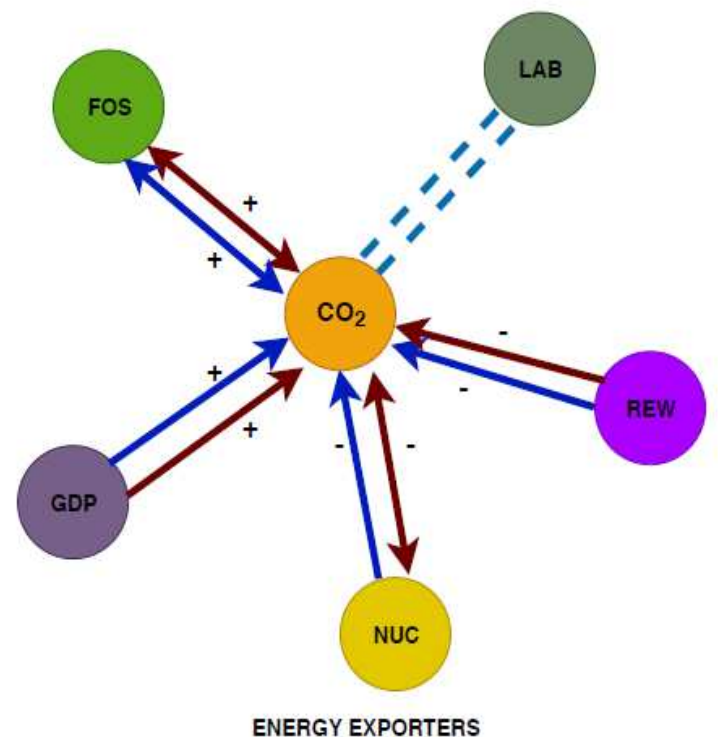

NERGY EXPORTERS

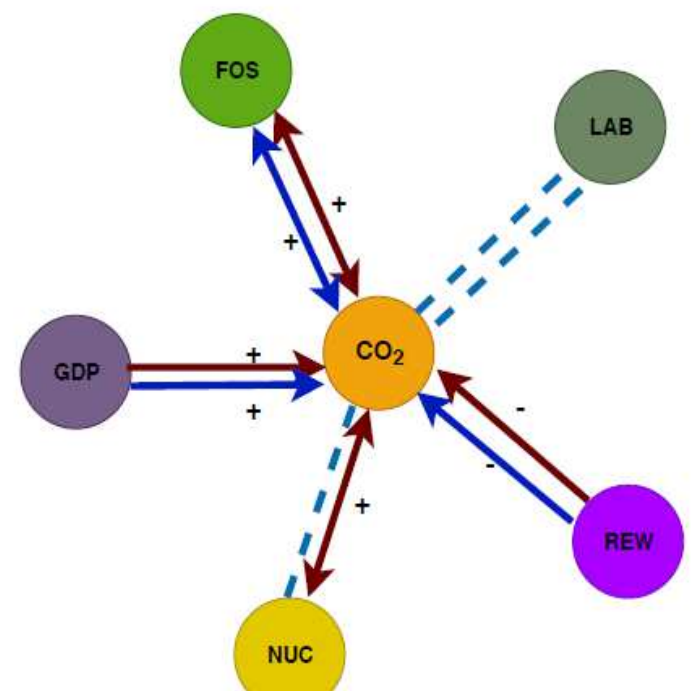

ENERGY IMPORTERS

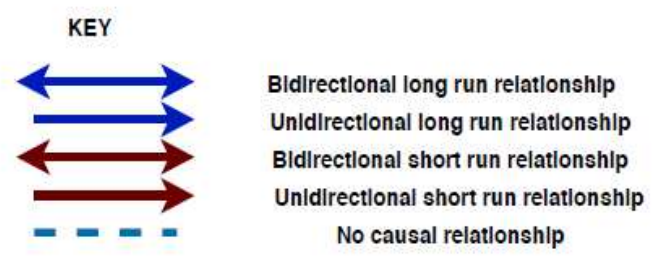

Figure 2: Graphical representation of two-sided and one sided causal affiliations among variables in different country group.

\subsection{4.}

\section{PVECM granger causality}


In addition, the panel vector error correction model (PVECM) was applied in testing the granger causality. Although results from the estimation differ, the results are generally coherent with the results of casualties caused by $\mathrm{CO}_{2}$, GDP, NUC, REW and FOS employing the PMG estimator of the ARDL model. The PVCEM granger causality test samples were performed separately, as shown in table 15.

For main panel, considering energies and $\mathrm{CO}_{2}$ emissions relationship, FOS has a two way causal relationship with $\mathrm{CO}_{2}$ in the short run and long run as well. In the long run no causal effect was depicted for REW and $\mathrm{CO}_{2}$, nevertheless, in the short run a one way causal effect was felt from REW to $\mathrm{CO}_{2}$. Two way causal effect was felt between $\mathrm{NUC}$ and $\mathrm{CO}_{2}$ in the short run and in 505 the long run, a unidirectional causal effect was found from REW to $\mathrm{CO}_{2}$. Looking at energies and 506 economic growth relationship, GDP, has a bidirectional cause and effect association with NUC, 507 REW and FOS in the long run. Notwithstanding in the short run, GDP has a one way causal 508 relationship with NUC and FOR while a bidirectional causal effect relationship was found between REW and GDP.

Considering $\mathrm{CO}_{2}$ emissions and energy consumption relationships for energies importers, a two way causal association was felt between FOS and $\mathrm{CO}_{2}$ in the long run, however in the short 512 run, a unidirectional causal effect was felt from FOS to $\mathrm{CO}_{2}$. No causal relationship was found in 513 the long run between $\mathrm{REW}$ and $\mathrm{CO}_{2}$, however in the short run, a one way causal effect was depicted 514 from REW to $\mathrm{CO}_{2}$. Also a one way causal relationship was depicted from $\mathrm{NUC}$ to $\mathrm{CO}_{2}$ all in the 515 long and short run. This affirms the work done by (Wolde-Rufael and Menyah 2010) in nine 516 developed countries. Considering Energies and economic growth relationship, a directional cause 517 and effect association was felt between FOS and GDP in the long run however, a unidirectional 518 association was depicted from FOS and GDP. A two way causal effect was felt amidst REW and 
519 GDP in the long run however, in the short run a one way causal effect was found from REW to

520 GDP. Lastly, a unidirectional causal effect was depicted from NUC to GDP in the long run,

521 however no causal effect was depicted in the short run. Lastly on Energies exporters, energies and

$522 \mathrm{CO}_{2}$ emissions relationship, a bidirectional causal association was depicted among $\mathrm{FOS}$ and $\mathrm{CO}_{2}$

523 in the long run, however in the short a unidirectional causal effect was depicted from FOS to $\mathrm{CO}_{2}$.

524 No causal effect was revealed between REW and $\mathrm{CO}_{2}$ in the long run, as shown by Wang et al.

525 (2016) in their study in China but a unidirectional causal effect was felt from $\mathrm{CO}_{2}$ to $\mathrm{REW}$ in the

526 short run. A one way causal effect was found from $\mathrm{NUC}$ to $\mathrm{CO}_{2}$ in the long run but none was felt

527 in the short run. Considering Energies and economic growth relationship, a bidirectional causal

528 association amidst FOS and GDP in the long run but a one way causal effect was felt from FOS to

529 GDP in the short run. Both in the long and short, a one way causal effect was revealed from REW

530 to GDP run. Likewise in the long and short run, a one way causal effect from NUC to GDP was

531 felt.

\section{INSERT TABLE 15}

\section{Conclusion and policy implications}

The study examined the impact of nuclear energy, renewable energy, economic growth, labor

535 and fossil fuel consumption on $\mathrm{CO}_{2}$ emissions over the period 1990-2018 for 40 countries along

536 the BRI. For much exploitation, the countries were clustered based on being energy importer or 537 energy exporter. The econometric approach in this study are as follows; Pesaran CD test, Frees'test 538 and the Friedman test was used to determine the presence of cross sectional dependency among 539 the series. For stationarity, the CADF and the CIPS was used. The test result revealed the series in 540 this study were I(0) but turn to I(1). Since stationarity has been inferred, it was necessary to find 541 out the structural long run association of the variables, therefore Westerlund-Edgerton panel 
542 bootstrap cointegration test was applied. The results indicated the variables are cointegrated.

543 Lastly, in other to infer causality and the magnitude of the effect of the explanatory variables on

544 the response variable, the PMG estimator was employed. The results from the PMG can be

545 summarize as: (a) for the main panel, a significant two-way relationship amongst FOS and $\mathrm{CO}_{2}$ in

546 the long and short term. In the long term, there is a significant negative causal relationship from

547 REW to $\mathrm{CO}_{2}$, but it is not found in the short term. In the long run, there is a positive and significant

548 causal relationship between NUC and $\mathrm{CO}_{2}$, but in the short run, there is a one-way relationship

549 from NUC to $\mathrm{CO}_{2}$. (b) For energy importers, In the long run, $\mathrm{CO}_{2}$ is positively and significantly

550 correlated in a two-way causal relationship with FOS and NUC, while REW is negatively and

551 significantly correlated with $\mathrm{CO}_{2}$ in a one way. However, in the short term, there is a positive two-

552 way causal relationship between $\mathrm{FOS}$ and $\mathrm{CO}_{2}$, while there is a significant negative correlation

553 amongst REW and $\mathrm{CO}_{2}$. There is no causal relationship between $\mathrm{NUC}$ and $\mathrm{CO}_{2}$ in the short term.

554 (c) For energy exporters, in the long run, there is a significant positive two-way relationship 555 between FOS and $\mathrm{CO}_{2}$, and a significant negative one-way causal relationship from NUC and 556 REW to $\mathrm{CO}_{2}$. Similarly, in the short term, the influence of REW and $\mathrm{NUC}$ on $\mathrm{CO}_{2}$ is negative and 557 significant one-way causality, while the influence of $\mathrm{CO}_{2}$ on FOS is one-way causality.

558 The long-term elasticities and causalities between variables are essential for the effective 559 design of energy policies. The empirical analysis of this study shows that the energy consumption 560 of renewable energy, nuclear energy and fossil fuels all contribute to economic growth. However, 561 with regards to the quality environmental, renewable energy is a better choice. To this extent, 562 increase in consumption of renewable energy abridge $\mathrm{CO}_{2}$ intensity along the $\mathrm{BRI}$.

a) Therefore governments in the various energy groups can subsidize the development 564 and use of renewable energy by imposing higher taxes on fossil fuels. Again subsidies 
could come in the form of research and development, as well as credit, low-cost loans and production tax credits to renewable energy developers to induce the growth of renewable energy products.

b) Again, policymakers along the BRI need to develop policies that encourage publicprivate partnerships by providing opportunities for small investors to produce renewable energy from different sources. Recognition of the disadvantages of nuclear and fossil fuels and the advantages of using renewable sources of energy are also important for improving the quality of the environment, governments of both energy importing and exporting countries should increase trade activities, formulate green trade policies and ensure sustainable development.

c) Trade activities provide a channel for developed countries to transfer technology to emerging economies. Such technology transfer aids reduce production costs and increase production of renewable energy. In conclusion, different business policies, such as feed-in tariffs and home solar panels, should also give companies the privilege of selling excess renewable energy, and these policies must be well implemented to encourage consumption.

\section{Abbreviations}

GDP: Gross domestic product, REW: Renewable energy, ARDL: Autoregressive distributed lag, VAR: Vector auto regression model, GMM: Generalized method of moments, PMG: Pooled mean group, AMG: Augmented mean group, CU-BC: Continuously-Updated Bias-Corrected, CCEMG: Common correlated effects mean group, VIF: Variance Inflation Factor, PVECM panel vector error correction technique, PMG: Pooled mean group, CADF cross-sectionally dependent augmented dickey fuller, CIPS cross-sectionally, CSD: Cross sectional dependency, NUC: Nuclear energy, REW: Renewable energy, LAB: Labor force, FOS: Fossil fuel, EU: European 
590 Union, BRI: Belt and Road Initiative, BRICS: Brazil, Russia, India, China and South Africa,

591 OECD: Organization for Economic Co-operation and Development. MENA: Middle east and

592 North Africa, BRI: Belt and Road Initiative

593 Acknowledgements

594 None

595 Authors' contributions

596 Professor JIYING Wu supervised the research from the beginning to the end. Olivier Joseph Abban

597 conceived the study, collected the data, estimated the econometric model and drafted the 598 manuscript. The authors read and approved the final manuscript.

$599 \quad$ Funding

600 This study is sponsored by the Humanities and Social Science Research Youth Fund Project of 601 Ministry of Education of China (17YJC910008) granted to Professor Jiying Wu.

602 Availability of data and materials

603 All data used in this study are publicly available online. The information on the sources of data is 604 provided in Table 2.

605 Ethics approval and consent to participate

606 Not applicable

607 Consent for publication

608 Not applicable

609 Competing interests

610 The authors declare that they have no competing interests.

611

612

613

614

615

616 


\section{References}

1. Abban OJ, Wu J, Mensah IA (2020) Analysis on the nexus amid CO 2 emissions, energy intensity, economic growth, and foreign direct investment in Belt and Road economies: does the level of income matter? Environmental Science and Pollution Research 27:11387-11402.

2. Acaravci A, Ozturk I (2010) Electricity consumption-growth nexus: evidence from panel data for transition countries Energy Economics 32:604-60.

3. Adib R et al. (2015) Renewables 2015 global status report Paris: REN21 Secretariat 83:84

4. Al-Mulali $U$ (2014) Investigating the impact of nuclear energy consumption on GDP growth and CO2 emission: A panel data analysis Progress in Nuclear Energy 73:172-178. Ameyaw B, Yao L (2018) Analyzing the impact of GDP on CO2 emissions and forecasting Africa's total CO2 emissions with non-assumption driven bidirectional long short-term memory Sustainability 10:3110.

5. Apergis N, Payne JE (2015) Renewable energy, output, carbon dioxide emissions, and oil prices: evidence from South America Energy Sources, Part B: Economics, Planning, and Policy 10:281287.

6. Baek J (2015) A panel cointegration analysis of CO2 emissions, nuclear energy and income in major nuclear generating countries Applied Energy 145:133-138.

7. Baloch MA, Mahmood N, Zhang JW (2019) Effect of natural resources, renewable energy and economic development on $\mathrm{CO} 2$ emissions in BRICS countries Science of the Total Environment 678:632-638.

8. Begum RA, Sohag K, Abdullah SMS, Jaafar M (2015) CO2 emissions, energy consumption, economic and population growth in Malaysia Renewable and Sustainable Energy Reviews 41:594-601.

9. Bekun FV, Alola AA, Sarkodie SA (2019) Toward a sustainable environment: Nexus between CO2 emissions, resource rent, renewable and nonrenewable energy in 16-EU countries Science of the Total Environment 657:1023-1029.

10. Beşe E, Kalayci S (2019) Environmental Kuznets curve (EKC): Empirical relationship between economic growth, energy consumption, and $\mathrm{CO} 2$ emissions: Evidence from 3 developed countries Panoeconomicus:1-26.

11. Bilgili $F$, Koçak $E$, Bulut Ü (2016) The dynamic impact of renewable energy consumption on $\mathrm{CO} 2$ emissions: a revisited Environmental Kuznets Curve approach Renewable and Sustainable Energy Reviews 54:838-845.

12. Breusch TS, Pagan AR (1980) The Lagrange multiplier test and its applications to model specification in econometrics The review of economic studies 47:239-253. DOI: $10.2307 / 2297111$

13. Cai $Y$, Sam CY, Chang T (2018) Nexus between clean energy consumption, economic growth and CO2 emissions Journal of Cleaner Production 182:1001-1011

14. Chen T, Gozgor G, Koo CK, Lau CKM (2020) Does international cooperation affect CO 2 emissions? Evidence from OECD countries Environmental Science and Pollution Research:1-9

15. Chen Y, Wang Z, Zhong Z (2019) CO2 emissions, economic growth, renewable and nonrenewable energy production and foreign trade in China Renewable energy 131:208-216

16. De Hoyos R, Sarafidis V (2006) XTCSD: Stata module to test for cross-sectional dependence in panel data models. The stata journal 6:482-496

17. de Souza Mendonça AK, Barni GdAC, Moro MF, Bornia AC, Kupek E, Fernandes L (2020) Hierarchical modeling of the 50 largest economies to verify the impact of GDP, population and renewable energy generation in $\mathrm{CO} 2$ emissions Sustainable Production and Consumption 22:5867 
18. Do T, Dinh H (2020) Short-and long-term effects of GDP, energy consumption, FDI, and trade openness on $\mathrm{CO} 2$ emissions Accounting 6:365-372

19. Dogan E, Seker F (2016) Determinants of $\mathrm{CO} 2$ emissions in the European Union: The role of renewable and non-renewable energy Renewable Energy 94:429-439

20. Dong K, Hochman G, Zhang Y, Sun R, Li H, Liao H (2018a) CO2 emissions, economic and population growth, and renewable energy: Empirical evidence across regions Energy Economics 75:180-192

21. Dong K, Sun R, Hochman G (2017) Do natural gas and renewable energy consumption lead to less CO2 emission? Empirical evidence from a panel of BRICS countries Energy 141:1466-1478

22. Dong K, Sun R, Jiang H, Zeng X (2018b) CO2 emissions, economic growth, and the environmental Kuznets curve in China: what roles can nuclear energy and renewable energy play? Journal of cleaner production 196:51-63

23. Haseeb A, Xia E, Baloch MA, Abbas K (2018) Financial development, globalization, and CO 2 emission in the presence of EKC: evidence from BRICS countries Environmental Science and Pollution Research 25:31283-31296

24. Hashmi R, Alam K (2019) Dynamic relationship among environmental regulation, innovation, CO2 emissions, population, and economic growth in OECD countries: A panel investigation Journal of cleaner production 231:1100-1109

25. Hassan ST, Tarar ZH (2020) Does nuclear energy is better for mitigating CO2 emissions in BRICS countries? An empirical analysis Nuclear Engineering and Technology

26. Hewitt GF, Collier JG (2018) Introduction to nuclear power. CRC Press,

27. Hori M Role of nuclear energy in the long-term global energy perspective. In: Proceedings of OECD/NEA First Information Exchange Meeting on Nuclear Production of Hydrogen, Paris, France, 2000. p 25

28. IEA O (2015) Energy and climate change, world energy outlook special report. Paris, France: OECD, IEA

29. Im KS, Pesaran MH, Shin Y (2003) Testing for unit roots in heterogeneous panels Journal of econometrics 115:53-74

30. Irandoust M (2016) The renewable energy-growth nexus with carbon emissions and technological innovation: Evidence from the Nordic countries Ecological indicators 69:118-125

31. Ito K (2017) CO2 emissions, renewable and non-renewable energy consumption, and economic growth:

32. Evidence from panel data for developing countries International Economics 151:1-6

33. Jaforullah M, King A (2015) Does the use of renewable energy sources mitigate $\mathrm{CO} 2$ emissions? A reassessment of the US evidence Energy Economics 49:711-717

34. Jebli MB, Youssef SB, Ozturk I (2016) Testing environmental Kuznets curve hypothesis: The role of renewable and non-renewable energy consumption and trade in OECD countries Ecological Indicators 60:824-831

35. Kahia M, Aïssa MSB, Lanouar C (2017) Renewable and non-renewable energy use-economic growth nexus: The case of MENA Net Oil Importing Countries Renewable and Sustainable Energy Reviews 71:127-140

36. Khattak SI, Ahmad M, Khan ZU, Khan A (2020) Exploring the impact of innovation, renewable energy consumption, and income on $\mathrm{CO} 2$ emissions: new evidence from the BRICS economies Environmental Science and Pollution Research:1-16

37. Liu Y, Hao Y (2018) The dynamic links between CO2 emissions, energy consumption and economic development in the countries along "the Belt and Road" Science of the Total Environment 645:674-683 
38. Liu Z, Feng K, Davis SJ, Guan D, Chen B, Hubacek K, Yan J (2016) Understanding the energy consumption and greenhouse gas emissions and the implication for achieving climate change mitigation targets Applied Energy 184:737-741

39. Long X, Naminse EY, Du J, Zhuang J (2015) Nonrenewable energy, renewable energy, carbon dioxide emissions and economic growth in China from 1952 to 2012 Renewable and Sustainable Energy Reviews 52:680-688

40. Luqman M, Ahmad N, Bakhsh K (2019) Nuclear energy, renewable energy and economic growth in Pakistan: Evidence from non-linear autoregressive distributed lag model Renewable Energy 139:1299-1309

41. Mahmood N, Wang Z, Zhang B (2020) The role of nuclear energy in the correction of environmental pollution: Evidence from Pakistan Nuclear Engineering and Technology 52:13271333

42. Menyah K, Wolde-Rufael Y (2010) Energy consumption, pollutant emissions and economic growth in South Africa Energy economics 32:1374-1382

43. Munir $Q$, Lean HH, Smyth R (2020) CO2 emissions, energy consumption and economic growth in the ASEAN-5 countries: A cross-sectional dependence approach Energy Economics 85:104571

44. Nathaniel SP, Iheonu CO (2019) Carbon dioxide abatement in Africa: The role of renewable and non-renewable energy consumption Science of the Total Environment 679:337-345

45. Ohler A, Fetters I (2014) The causal relationship between renewable electricity generation and GDP growth: A study of energy sources Energy economics 43:125-139

46. Omri A, Mabrouk NB, Sassi-Tmar A (2015) Modeling the causal linkages between nuclear energy, renewable energy and economic growth in developed and developing countries Renewable and Sustainable Energy Reviews 42:1012-1022

47. Pedroni P (2004) Panel cointegration: asymptotic and finite sample properties of pooled time series tests with an application to the PPP hypothesis Econometric theory 20:597-625

48. Pesaran $\mathrm{MH}$ (2007) A simple panel unit root test in the presence of cross-section dependence Journal of applied econometrics 22:265-312

49. Pesaran MH, Shin Y, Smith RP (1999) Pooled mean group estimation of dynamic heterogeneous panels Journal of the American Statistical Association 94:621-634

50. Petroleum B (2018) Renewable Energy-BP Statistical Review of World Energy 2018 British Petroleum: London, UK

51. Ren21 R (2016) Global status report REN21 secretariat, Paris 2016

52. Richmond AK, Kaufmann RK (2006) Energy prices and turning points: the relationship between income and energy use/carbon emissions The Energy Journal:157-180

53. Saidi K, Mbarek MB (2016) Nuclear energy, renewable energy, CO2 emissions, and economic growth for nine developed countries: Evidence from panel Granger causality tests Progress in Nuclear Energy 88:364-374

54. Saidi K, Omri A (2020) Reducing CO2 emissions in OECD countries: Do renewable and nuclear energy matter? Progress in Nuclear Energy 126:103425

55. Sasana H, Ghozali I (2017) The impact of fossil and renewable energy consumption on the economic growth in Brazil, Russia, India, China and South Africa International Journal of Energy Economics and Policy 7:194-200

56. Saud S, Chen S, Haseeb A (2019) Impact of financial development and economic growth on environmental quality: an empirical analysis from Belt and Road Initiative (BRI) countries Environmental Science and Pollution Research 26:2253-2269

57. Schandl H et al. (2016) Decoupling global environmental pressure and economic growth: scenarios for energy use, materials use and carbon emissions Journal of cleaner production $132: 45-56$ 
58. Sebri M (2015) Use renewables to be cleaner: meta-analysis of the renewable energy consumption-economic growth nexus Renewable and Sustainable Energy Reviews 42:657-665

59. Shahbaz M, Solarin SA, Sbia R, Bibi S (2015) Does energy intensity contribute to CO2 emissions? A trivariate analysis in selected African countries Ecological indicators 50:215-224

60. Sulaiman C, Abdul-Rahim A (2018) Population growth and CO2 emission in Nigeria: a recursive ARDL approach Sage Open 8:2158244018765916

61. Thompson CG, Kim RS, Aloe AM, Becker BJ (2017) Extracting the variance inflation factor and other multicollinearity diagnostics from typical regression results Basic and Applied Social Psychology 39:81-90

62. Usman A, Ullah S, Ozturk I, Chishti MZ, Zafar SM (2020) Analysis of asymmetries in the nexus among clean energy and environmental quality in Pakistan Environmental Science and Pollution Research:1-12

63. Vo DH, Vo AT, Ho CM, Nguyen HM (2020) The role of renewable energy, alternative and nuclear energy in mitigating carbon emissions in the CPTPP countries Renewable Energy

64. Waheed R, Chang D, Sarwar S, Chen W (2018) Forest, agriculture, renewable energy, and CO2 emission Journal of Cleaner Production 172:4231-4238

65. Wang C-M, Hsueh H-P, Li F, Wu C-F (2019) Bootstrap ARDL on Health Expenditure, CO2 Emissions, and GDP Growth Relationship for 18 OECD Countries Frontiers in Public Health 7

66. Wang J, Dong K (2019) What drives environmental degradation? Evidence from 14 Sub-Saharan African countries Science of the Total Environment 656:165-173

67. Wang S, Li Q, Fang C, Zhou C (2016) The relationship between economic growth, energy consumption, and $\mathrm{CO} 2$ emissions: Empirical evidence from China Science of the Total Environment 542:360-371

68. Westerlund J, Edgerton DL (2007) A panel bootstrap cointegration test Economics letters 97:185-190

69. Wolde-Rufael Y, Menyah K (2010) Nuclear energy consumption and economic growth in nine developed countries Energy economics 32:550-556

70. Wu J, Abban OJ, Boadi AD, Haris M, Ocran P, Addo AA (2020) Exploring the relationships among CO 2 emissions, urbanization, economic growth, economic structure, energy consumption, and trade along the BRI based on income classification Energy, Ecology and Environment:1-19

71. Zhang G, Zhang N, Liao W (2018) How do population and land urbanization affect CO2 emissions under gravity center change? A spatial econometric analysis Journal of Cleaner Production 202:510-523 
Table 1: Recent empirical studies on the relationship among the variables.

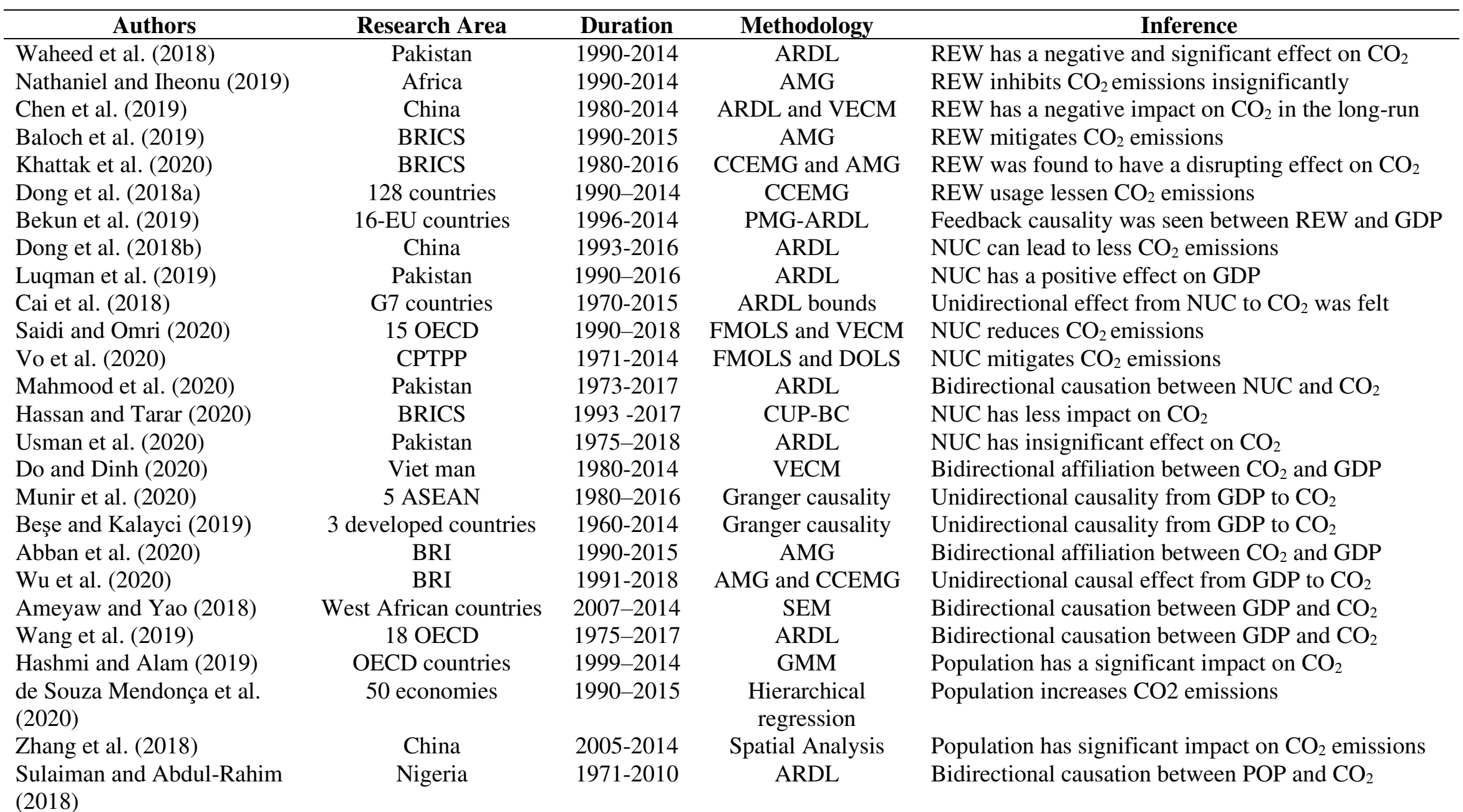

Note: $\mathrm{CO}_{2}=\mathrm{CO}_{2}$ emissions, $\mathrm{GDP}=$ economic growth, $\mathrm{REW}=$ renewable energy, $\mathrm{ARDL}=$ autoregressive distributed lag, VAR = vector auto regression model,

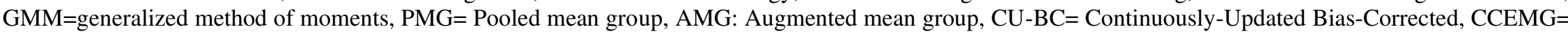
Common correlated effects mean group, EU= European Union, BRI= Belt and Road Initiative, BRICS= Brazil, Russia, India, China and South Africa, OECD= Organization for Economic Co-operation and Development. 
2 Table 2: Variable units and reference

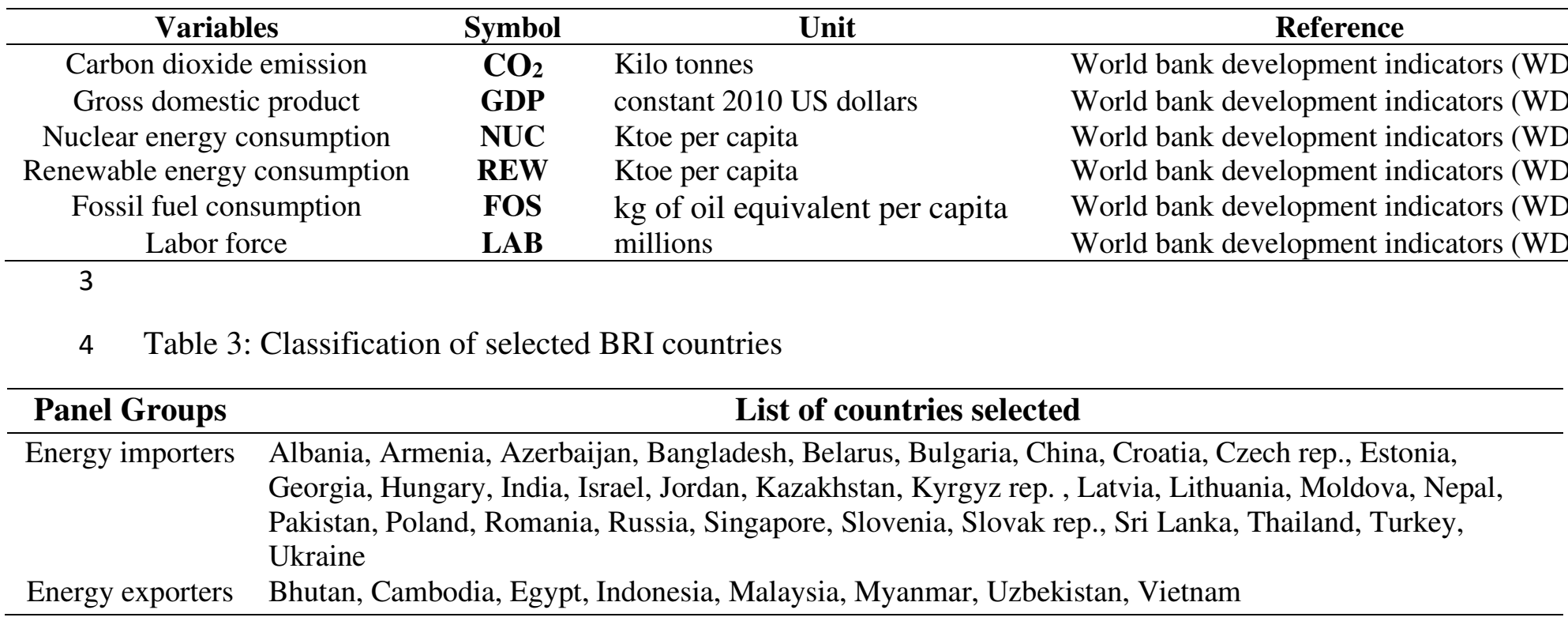

5

6 Table 4: Descriptive statistics

\begin{tabular}{lcccccc}
\hline \multicolumn{1}{c}{ Panel } & Variable & Mean & Std. dev. & Skewness & kurtossis & JB test \\
\hline Main panel & $\mathrm{CO}_{2}$ & 4.720 & 3.926 & 0.877 & 3.046 & $118.883^{\mathrm{a}}$ \\
& GDP & 7.785 & 1.331 & 0.006 & 2.242 & $22.126^{\mathrm{a}}$ \\
& $\mathrm{LAB}$ & 15.890 & 1.684 & 0.756 & 3.120 & $88.271^{\mathrm{a}}$ \\
& $\mathrm{NUC}$ & 7.523 & 2.198 & 1.414 & 4.103 & $355.601^{\mathrm{a}}$ \\
& $\mathrm{REW}$ & 2.761 & 0.608 & -1.498 & 6.741 & $885.580^{\mathrm{a}}$ \\
& FOS & 7.207 & 0.909 & -0.454 & 2.214 & $55.587^{\mathrm{a}}$ \\
Energy importers & $\mathrm{CO} 2$ & 5.125 & 3.985 & 0.762 & 2.841 & $78.458^{\mathrm{a}}$ \\
& GDP & 7.911 & 1.307 & 0.011 & 2.115 & $26.091^{\mathrm{a}}$ \\
& $\mathrm{LAB}$ & 15.688 & 1.698 & 1.064 & 3.609 & $163.329^{\mathrm{a}}$ \\
& $\mathrm{NUC}$ & 5.421 & 2.569 & 1.209 & 1.209 & $204.157^{\mathrm{a}}$ \\
& $\mathrm{REW}$ & 2.693 & 0.619 & -1.418 & 6.449 & $664.940^{\mathrm{a}}$ \\
& FOS & 7.318 & 0.886 & -0.660 & 2.594 & $63.696^{\mathrm{a}}$ \\
& $\mathrm{CO} 2$ & 2.129 & 1.073 & 1.399 & 3.006 & $44.481^{\mathrm{a}}$ \\
& GDP & 6.980 & 1.196 & -0.139 & 2.322 & $4.7951^{\mathrm{b}}$ \\
& LAB & 17.181 & 0.787 & 0.228 & 2.154 & $4.8157^{\mathrm{a}}$ \\
& $\mathrm{NUC}$ & 6.774 & 1.387 & 1.632 & 5.848 & $97.775^{\mathrm{a}}$ \\
& REW & 3.192 & 0.261 & -0.428 & 2.437 & $5.467^{\mathrm{c}}$ \\
& FOS & 6.498 & 0.718 & 0.500 & 2.361 & $7.349^{\mathrm{b}}$ \\
\hline
\end{tabular}


$7 \quad$ Note: All the variables are transformed as natural logarithms. Data for 37 BRI countries from 1991 to 2015.

8 Ascertaining if a variable follow a normal distribution, the jarque-bera test was utilized .It tests the $H_{O}$ that a given

9 variable is normally distributed.

10

11 Table 5: Pearson correlation analysis

\begin{tabular}{|c|c|c|c|c|c|c|c|}
\hline Variables & & $\mathrm{CO}_{2}$ & GDP & LAB & NUC & REW & FOS \\
\hline $\mathrm{CO}_{2}$ & Pearson corr. Sig.(2-tailed) & 1 & $\begin{array}{l}0.643^{\mathrm{b}} \\
(0.000)\end{array}$ & $\begin{array}{l}-0.213^{\mathrm{b}} \\
(0.000)\end{array}$ & $\begin{array}{l}0.423^{\mathrm{b}} \\
(0.000)\end{array}$ & $\begin{array}{l}-0.357^{b} \\
(0.000)\end{array}$ & $\begin{array}{l}0.875^{\mathrm{b}} \\
(0.000)\end{array}$ \\
\hline GDP & Pearson corr. Sig.(2-tailed) & & 1 & $\begin{array}{l}-0.336^{b} \\
(0.000)\end{array}$ & $\begin{array}{l}0.191^{b} \\
(0.000)\end{array}$ & $\begin{array}{l}-.417^{\mathrm{b}} \\
(0.000)\end{array}$ & $\begin{array}{l}0.761^{\mathrm{b}} \\
(0.000)\end{array}$ \\
\hline LAB & Pearson corr. Sig.(2-tailed) & & & 1 & $\begin{array}{c}-0.393^{b} \\
(0.000)\end{array}$ & $\begin{array}{l}0.422^{b} \\
(0.000)\end{array}$ & $\begin{array}{l}-0.354^{\mathrm{b}} \\
(0.000)\end{array}$ \\
\hline NUC & Pearson corr. Sig.(2-tailed) & & & & 1 & $\begin{array}{c}0.260 \\
(0.007)\end{array}$ & $\begin{array}{l}0.192^{\mathrm{b}} \\
(0.000)\end{array}$ \\
\hline REW & Pearson corr. Sig.(2-tailed) & & & & & 1 & $\begin{array}{l}-0.335^{\mathrm{b}} \\
(0.000)\end{array}$ \\
\hline FOS & Pearson corr. Sig.(2-tailed) & & & & & & 1 \\
\hline
\end{tabular}

12 Note: "b" significance of correlation is at 5\%. The 5\% level of statistical significance provides evidence that the

13 probability of rejecting or accepting the null hypothesis is a type 1 error.

14

Table 6: Multicolinearity test

\begin{tabular}{lcc}
\hline Model & \multicolumn{2}{c}{ Collinearity statistics } \\
\hline & Tolerance & VIF \\
\cline { 2 - 3 } Gross domestic product & 0.386 & 2.589 \\
Labor force & 0.628 & 1.592 \\
Alternative and renewable energy & 0.761 & 1.314 \\
Combustible renewable and waste & 0.665 & 1.503 \\
Fossil fuels & 0.410 & 2.438 \\
\hline
\end{tabular}


29 Table 7: Cross sectional dependence

\begin{tabular}{|c|c|c|c|c|c|c|c|}
\hline Panel group & Test statistics & $\mathrm{CO}_{2}$ & GDP & LAB & NUC & REW & FOS \\
\hline \multirow[t]{4}{*}{ Main panel } & Pesaran CD & $5.585^{\mathrm{a}}$ & $63.902^{\mathrm{a}}$ & $1.821^{\mathrm{c}}$ & $2.787^{\mathrm{a}}$ & $6.671^{\mathrm{a}}$ & $3.372^{\mathrm{a}}$ \\
\hline & & $(0.401)$ & $(0.626)$ & $(0.597)$ & $(0.466)$ & $(0.410)$ & $(0.589)$ \\
\hline & Frees & $6.015^{\mathrm{a}}$ & $14.263^{\mathrm{a}}$ & $14.027^{\mathrm{a}}$ & $7.357^{\mathrm{a}}$ & $4.146^{\mathrm{a}}$ & $5.774^{\mathrm{a}}$ \\
\hline & Friedman & $64.853^{\mathrm{a}}$ & $424.338^{\mathrm{a}}$ & $44.328^{c}$ & $50.544^{\mathrm{c}}$ & $68.455^{\mathrm{a}}$ & 0.005 \\
\hline \multirow[t]{4}{*}{ Energy importers } & Pesaran CD & $5.254^{\mathrm{a}}$ & $66.063^{\mathrm{a}}$ & $1.934^{\mathrm{c}}$ & $2.257^{b}$ & $6.176^{\mathrm{a}}$ & $2.389^{\mathrm{b}}$ \\
\hline & & $(0.411)$ & $(0.687)$ & $(0.603)$ & $(0.487)$ & $(0.342)$ & $(0.412)$ \\
\hline & Frees & $5.342^{\mathrm{a}}$ & $14.091^{\mathrm{a}}$ & $12.016^{\mathrm{a}}$ & $7.335^{\mathrm{a}}$ & $3.526^{\mathrm{a}}$ & $5.302^{\mathrm{a}}$ \\
\hline & Friedman & $61.630^{\mathrm{a}}$ & $441.107^{\mathrm{a}}$ & $48.635^{c}$ & $44.782^{\mathrm{c}}$ & $63.749^{a}$ & $56.835^{\mathrm{b}}$ \\
\hline \multirow[t]{4}{*}{ Energy exporters } & Pesaran CD & $2.127^{\mathrm{b}}$ & $2.954^{\mathrm{a}}$ & $1.854^{\mathrm{c}}$ & $2.682^{\mathrm{a}}$ & $2.224^{\mathrm{b}}$ & $2.173^{\mathrm{a}}$ \\
\hline & & $(0.439)$ & $(0.397)$ & $(0.377)$ & $(0.319)$ & $(0.311)$ & $(0.340)$ \\
\hline & Frees & $0.799^{\mathrm{a}}$ & $0.549^{\mathrm{a}}$ & $0.287^{\mathrm{a}}$ & $0.334^{\mathrm{a}}$ & $0.425^{\mathrm{a}}$ & $0.235^{\mathrm{a}}$ \\
\hline & Friedman & $32.972^{\mathrm{a}}$ & $47.956^{\mathrm{a}}$ & $37.647^{\mathrm{a}}$ & $46.065^{\mathrm{a}}$ & $35.675^{\mathrm{a}}$ & $32.810^{\mathrm{a}}$ \\
\hline
\end{tabular}

30 Note: $H_{0}$ : existence of cross sectional independence, a,b,c denote statistical significance at $1 \%, 5 \%, 10 \%$. () is the absolute

31 correlation of the residuals.

32

33

34

35

36

37

38

39

40

41

42

43

44

45

46

47

48

49

50

51

52 


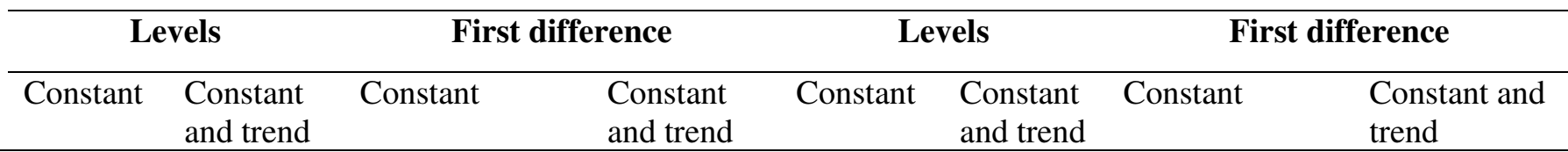

Main panel

$\begin{array}{lllllllll}\mathrm{CO}_{2} & -1.288 & -2.591 & -4.701^{\mathrm{a}} & -4.922^{\mathrm{a}} & -1.260 & -2.621 & -3.726^{\mathrm{b}} & -4.038^{\mathrm{a}} \\ \mathrm{GDP} & -2.424 & -2.612 & -4.234^{\mathrm{a}} & -4.376^{\mathrm{a}} & -2.392 & -2.282 & -3.277^{\mathrm{b}} & -3.352^{\mathrm{a}} \\ \mathrm{LAB} & -1.690 & -1.900 & -3.213^{\mathrm{b}} & -3.663^{\mathrm{b}} & -2.048 & -2.169 & -2.551^{\mathrm{a}} & -3.023^{\mathrm{b}} \\ \mathrm{NUC} & -1.369 & -2.609 & -4.674^{\mathrm{a}} & -4.895^{\mathrm{a}} & -1.017 & -2.380 & -3.441^{\mathrm{b}} & -3.719^{\mathrm{a}} \\ \mathrm{REW} & 2.256 & -2.605 & -5.164^{\mathrm{a}} & -5.309^{\mathrm{a}} & -2.012 & -2.126 & -3.541^{\mathrm{a}} & -3.752^{\mathrm{a}} \\ \text { FOS } & -1.698 & -2.527 & -4.665^{\mathrm{a}} & -4.985^{\mathrm{a}} & -1.928 & -2.504 & -3.131^{\mathrm{b}} & -3.511^{\mathrm{a}}\end{array}$

\section{Energy importers}

\begin{tabular}{|c|c|c|c|c|c|c|c|c|}
\hline $\mathrm{CO}_{2}$ & -1.276 & -2.428 & $-4.813^{\mathrm{a}}$ & $-5.043^{\mathrm{a}}$ & -1.178 & -2.560 & $-3.710^{\mathrm{a}}$ & $-4.086^{\mathrm{a}}$ \\
\hline GDP & -2.607 & -2.469 & $-4.021^{\mathrm{a}}$ & $-4.216^{\mathrm{b}}$ & -2.996 & -2.977 & $-3.339^{\mathrm{a}}$ & $-3.430^{\mathrm{a}}$ \\
\hline $\mathrm{LAB}$ & -1.741 & -2.111 & $-3.292^{b}$ & $-3.737^{\mathrm{a}}$ & -2.074 & -2.496 & $-2.722^{\mathrm{a}}$ & $-3.217^{\mathrm{a}}$ \\
\hline NUC & -1.314 & -2.627 & $-4.662^{\mathrm{a}}$ & $-4.911^{\mathrm{a}}$ & -0.957 & -2.444 & $-3.483^{\mathrm{a}}$ & $-3.782^{\mathrm{a}}$ \\
\hline REW & -2.314 & -2.610 & $-5.157^{\mathrm{a}}$ & $-5.316^{\mathrm{a}}$ & -2.069 & -2.217 & $-3.587^{\mathrm{a}}$ & $-3.817^{\mathrm{a}}$ \\
\hline FOS & -1.763 & -2.610 & $-4.772^{\mathrm{a}}$ & $-5.079^{a}$ & -1.983 & -2.565 & $-3.191^{b}$ & $-3.556^{\mathrm{a}}$ \\
\hline \multicolumn{9}{|c|}{ Energy exporters } \\
\hline $\mathrm{CO}_{2}$ & -2.035 & -2.786 & $-3.836^{\mathrm{a}}$ & $-3.804^{\mathrm{a}}$ & -2.080 & -2.873 & $-4.481^{\mathrm{a}}$ & $-4.154^{\mathrm{a}}$ \\
\hline GDP & -2.389 & -2.310 & $-3.75^{\mathrm{a}}$ & $-3.745^{\mathrm{a}}$ & -2.536 & -2.120 & $-3.861^{\mathrm{a}}$ & $-4.021^{\mathrm{a}}$ \\
\hline LAB & -1.552 & -1.342 & $-2.519^{\mathrm{a}}$ & $-3.124^{b}$ & -1.380 & -2.129 & $-2.731^{\mathrm{a}}$ & $-2.932^{b}$ \\
\hline NUC & -1.471 & -2.114 & $-4.454^{\mathrm{a}}$ & $-4.492^{\mathrm{a}}$ & -1.586 & -2.036 & $-3.480^{\mathrm{a}}$ & $-2.936^{\mathrm{c}}$ \\
\hline REW & -2.562 & -3.883 & $-5.892^{\mathrm{a}}$ & $-5.985^{\mathrm{a}}$ & -1.377 & -2.344 & $-2.940^{c}$ & $-4.006^{\mathrm{b}}$ \\
\hline FOS & -2.167 & -3.242 & $-3.781^{\mathrm{a}}$ & $-3.701^{b}$ & -2.808 & -2.072 & $-4.667^{\mathrm{a}}$ & $-4.430^{\mathrm{a}}$ \\
\hline
\end{tabular}

54 Note: CIPS: H0 is "series have unit root for each panel". CADF: H0 is "series have unit root for each panel". a, b,c indicate

55 Statistical significance at $1 \%, 5 \%, 10 \%$ level respectively.

58 Table 9: westerlund's panel cointegration test results

\begin{tabular}{lcccccccc}
\hline \multirow{2}{*}{ Country groups } & \multicolumn{2}{c}{$\boldsymbol{G}_{\boldsymbol{\tau}}$} & \multicolumn{2}{c}{$\boldsymbol{G}_{\boldsymbol{\alpha}}$} & \multicolumn{2}{c}{$\boldsymbol{P}_{\boldsymbol{\tau}}$} & \multicolumn{2}{c}{$\boldsymbol{P}_{\boldsymbol{\alpha}}$} \\
\cline { 2 - 9 } & Value & $\begin{array}{c}\text { Robust } \\
\text { p-value }\end{array}$ & Value & $\begin{array}{l}\text { Robust } \\
\text { p-value }\end{array}$ & Value & $\begin{array}{l}\text { Robust } \\
\text { p-value }\end{array}$ & Value & $\begin{array}{c}\text { Robust } \\
\text { p-value }\end{array}$ \\
\hline Main panel & $-2.566^{\mathrm{a}}$ & $(0.000)$ & $-7.212^{\mathrm{a}}$ & $(0.007)$ & $-14.291^{\mathrm{b}}$ & $(0.030)$ & $-7.501^{\mathrm{b}}$ & $(0.021)$ \\
Energy importers & $-2.609^{\mathrm{a}}$ & $(0.000)$ & $-7.715^{\mathrm{b}}$ & $(0.040)$ & $-13.495^{\mathrm{c}}$ & $(0.012)$ & $-7.704^{\mathrm{a}}$ & $(0.003)$ \\
Energy exporters & $-3.208^{\mathrm{b}}$ & $(0.020)$ & $-19.732^{\mathrm{a}}$ & $(0.000)$ & $-13.210^{\mathrm{a}}$ & $(0.000)$ & $-50.989^{\mathrm{a}}$ & $(0.000)$ \\
\hline
\end{tabular}

59 Note: he optimal lag length was determined by AIC, and the width of the bartlett nucleus was also set as 1 . In the

60 cointegration test, we consider a constant, but there is no definite trend, and we report a robust p-value. 
63 Table 10: Pedroni's panel cointegration test results

\begin{tabular}{llcccccc}
\hline Country groups & \multicolumn{4}{c}{ Panel statistics } & \multicolumn{3}{c}{ Group statistics } \\
\cline { 2 - 8 } & V-statistic & Rho-statistic & PP-statistic & ADF-statistic & Rho-statistic & PP-statistic & ADF-statistic \\
\hline Main panel & -0.679 & 4.813 & $-9.240^{\mathrm{a}}$ & $-9.525^{\mathrm{a}}$ & 4.537 & $-11.439^{\mathrm{a}}$ & $-11.898^{\mathrm{a}}$ \\
Energy importers & -1.887 & 2.638 & $-6.950^{\mathrm{a}}$ & $-7.467^{\mathrm{a}}$ & 5.162 & $-10.324^{\mathrm{a}}$ & $-7.354^{\mathrm{a}}$ \\
Energy exporters & $2.4262^{\mathrm{c}}$ & $-2.356^{\mathrm{c}}$ & $-13.119^{\mathrm{a}}$ & $-16.599^{\mathrm{a}}$ & 1.159 & $-6.538^{\mathrm{a}}$ & $-6.757^{\mathrm{a}}$ \\
\hline
\end{tabular}

64 Note: $a, b, c$ denote the rejection of the null hypothesis at $1 \%, 5 \%$ and $10 \%$ significance level. The pedroni

65 cointegration test assumes the null hypothesis of no cointegration.

66

67 Table 11: Long and short run estimations results for main panel

\begin{tabular}{lcccccc}
\hline Dependent var. & CO $_{2}$ (eq.15) & GDP(eq.16) & LAB(eq.17) & NUC(eq.18) & REW(eq.19) & FOS(eq.20) \\
\hline Long-run coeff. & & & & & & \\
$\mathrm{CO}_{2}$ & - & 0.078 & -0.215 & 0.109 & -0.116 & $0.697^{\mathrm{a}}$ \\
$\mathrm{GDP}$ & $0.890^{\mathrm{a}}$ & - & $0.489^{\mathrm{b}}$ & $0.269^{\mathrm{a}}$ & $0.356^{\mathrm{a}}$ & $0.288^{\mathrm{c}}$ \\
$\mathrm{LAB}$ & -0.078 & 0.345 & - & -0.112 & $-0.940^{\mathrm{a}}$ & $0.345^{\mathrm{a}}$ \\
$\mathrm{NUC}$ & $0.134^{\mathrm{a}}$ & $0.152^{\mathrm{c}}$ & 0.06 & - & 1.534 & -0.761 \\
$\mathrm{REW}$ & $-0.416^{\mathrm{a}}$ & $0.281^{\mathrm{a}}$ & 0.112 & -0.044 & - & -0.056 \\
FOS & $0.701^{\mathrm{a}}$ & $0.314^{\mathrm{a}}$ & $0.484^{\mathrm{a}}$ & $0.111^{\mathrm{a}}$ & -0.095 & - \\
Ect & $-0.186^{\mathrm{a}}$ & $-0.861^{\mathrm{a}}$ & $-0.206^{\mathrm{a}}$ & $-0.788^{\mathrm{a}}$ & $-0.329^{\mathrm{a}}$ & $-0.202^{\mathrm{a}}$ \\
Short-run coeff & & & & & - \\
$\Delta \mathrm{CO} 2$ & - & 0.257 & 1.158 & -0.048 & -0.027 & $2.948^{\mathrm{a}}$ \\
$\Delta \mathrm{GDP}$ & $0.116^{\mathrm{b}}$ & - & 0.135 & 0.048 & 0.115 & $0.744^{\mathrm{a}}$ \\
$\Delta \mathrm{LAB}$ & 0.045 & $0.261^{\mathrm{c}}$ & - & $0.064^{\mathrm{c}}$ & 0.014 & $-0.033^{\mathrm{b}}$ \\
$\Delta \mathrm{NUC}$ & $0.136^{\mathrm{c}}$ & $-0.226^{\mathrm{b}}$ & 1.850 & - & -0.283 & 4.968 \\
$\Delta \mathrm{REW}$ & -0.084 & $0.127^{\mathrm{c}}$ & -1.416 & 0.066 & - & 0.429 \\
$\Delta$ FOS & $0.169^{\mathrm{a}}$ & $0.368^{\mathrm{a}}$ & -0.280 & $-0.139^{\mathrm{c}}$ & 0.018 & - \\
\hline Hausman test value & 4.49 & 1.88 & 0.76 & 2.92 & 6.12 & 3.87 \\
p-value & 0.732 & 0.865 & 0.979 & 0.359 & 0.294 & 0.567 \\
\hline
\end{tabular}

68 Note: a, b, c refer to level of significance at $1 \%, 5 \%$ and $10 \%$. The results obtained in table 10, 11 and 12 were as a 69 results of estimating equations (15) to (20).

70

71

72

73

74

75

76

77

78

79 
80 Table 12: Long and short run estimations results for energy importers

\begin{tabular}{|c|c|c|c|c|c|c|}
\hline Dependent var. & $\mathrm{CO}_{2}$ (eq.15) & GDP(eq.16) & LAB(eq.17) & NUC(eq.18) & REW(eq.19) & FOS(eq.20) \\
\hline \multicolumn{7}{|l|}{ Long-run coeff. } \\
\hline $\mathrm{CO}_{2}$ & 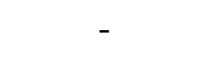 & 0.485 & 0.136 & $0.430^{\mathrm{c}}$ & -0.063 & $1.630^{\mathrm{a}}$ \\
\hline GDP & $0.568^{\mathrm{a}}$ & - & $1.294^{\mathrm{a}}$ & $0.165^{\mathrm{c}}$ & $1.208^{\mathrm{c}}$ & $1.122^{\mathrm{a}}$ \\
\hline LAB & 0.031 & 0.261 & - & 0.361 & 0.607 & 0.102 \\
\hline NUC & $0.169^{\mathrm{b}}$ & $0.404^{c}$ & -0.484 & - & -0.487 & 0.007 \\
\hline REW & $-0.293^{b}$ & $0.281^{\mathrm{c}}$ & -0.088 & 0.013 & - & 0.084 \\
\hline FOS & $1.378^{\mathrm{a}}$ & $0.029^{\mathrm{a}}$ & $0.079^{\mathrm{a}}$ & 0.114 & -0.016 & - \\
\hline Ect & $-0.114^{\mathrm{a}}$ & $-0.264^{b}$ & $-0.399^{\mathrm{b}}$ & $-0.212^{\mathrm{a}}$ & $-0.335^{\mathrm{a}}$ & $-0.205^{\mathrm{a}}$ \\
\hline \multicolumn{7}{|l|}{ Short-run coeff } \\
\hline$\Delta \mathrm{CO}_{2}$ & - & $0.063^{c}$ & 1.573 & -0.276 & -0.019 & $3.703^{c}$ \\
\hline$\triangle \mathrm{GDP}$ & $0.280^{\mathrm{b}}$ & - & 0.478 & 0.028 & $0.386^{\mathrm{c}}$ & $0.649^{\mathrm{a}}$ \\
\hline$\triangle \mathrm{LAB}$ & -0.057 & $0.167^{b}$ & - & -0.377 & 0.518 & -0.252 \\
\hline$\triangle \mathrm{NUC}$ & 0.048 & -0.075 & -0.057 & - & -0.534 & 0.041 \\
\hline$\triangle \mathrm{REW}$ & $-0.322^{\mathrm{b}}$ & $0.215^{\mathrm{a}}$ & -1.447 & 0.065 & - & 0.319 \\
\hline$\triangle \mathrm{FOS}$ & $0.180^{\mathrm{a}}$ & $0.272^{\mathrm{a}}$ & -0.218 & -0.148 & 0.169 & - \\
\hline Hausman test value & 1.48 & 0.97 & 1.45 & 2.01 & 0.76 & 2.08 \\
\hline p-value & 0.56 & 0.43 & 0.29 & 0.78 & 0.24 & 0.61 \\
\hline
\end{tabular}

81 Note: $a, b, c$ refer to level of significance at $1 \%, 5 \%$ and $10 \%$. The results obtained in table 10,11 and 12 were as a

82 results of estimating equations (16) to (21).

83

84 Table 13: Long and short run estimations results for energy exporters

\begin{tabular}{|c|c|c|c|c|c|c|}
\hline Dependent var. & $\mathrm{CO}_{2}$ (eq.15) & GDP(eq.16) & LAB(eq.17) & NUC(eq.18) & REW(eq.19) & FOS(eq.20) \\
\hline \multicolumn{7}{|l|}{ Long-run coeff. } \\
\hline $\mathrm{CO}_{2}$ & - & $0.574^{\mathrm{a}}$ & $0.428^{\mathrm{a}}$ & 0.039 & 0.301 & $0.689^{\mathrm{a}}$ \\
\hline GDP & $0.264^{\mathrm{a}}$ & - & -0.283 & 0.109 & $0.140^{c}$ & $0.712^{b}$ \\
\hline LAB & -0.217 & 1.598 & - & -0.041 & -0.247 & 0.596 \\
\hline NUC & $-0.473^{\mathrm{c}}$ & $-0.149^{\mathrm{a}}$ & $-0.104^{\mathrm{c}}$ & - & 0.179 & -5.525 \\
\hline REW & $-0.528^{\mathrm{a}}$ & $0.027^{b}$ & -0.122 & 0.0382 & - & -0.916 \\
\hline FOS & $0.518^{\mathrm{a}}$ & $0.131^{\mathrm{a}}$ & $0.113^{\mathrm{a}}$ & 0.121 & $0.145^{\mathrm{c}}$ & - \\
\hline Ect & $-0.319^{a}$ & $-0.147^{b}$ & $-0.015^{b}$ & $-0.242^{\mathrm{b}}$ & $-0.441^{b}$ & $-0.232^{\mathrm{a}}$ \\
\hline \multicolumn{7}{|l|}{ Short-run coeff } \\
\hline$\Delta \mathrm{CO}_{2}$ & - & 0.266 & -0.914 & -0.219 & -0.315 & $0.142^{b}$ \\
\hline$\triangle \mathrm{GDP}$ & $0.071^{\mathrm{c}}$ & - & -2.478 & 0.089 & $0.079^{c}$ & $0.989^{\mathrm{b}}$ \\
\hline$\triangle \mathrm{LAB}$ & 0.268 & $0.473^{\mathrm{c}}$ & - & 0.042 & 0.125 & -1.034 \\
\hline$\triangle \mathrm{NUC}$ & $-0.629^{c}$ & $0.417^{\mathrm{c}}$ & $-0.680^{\mathrm{c}}$ & - & 1.194 & $-0.499^{b}$ \\
\hline$\triangle \mathrm{REW}$ & $-0.121^{\mathrm{b}}$ & $0.218^{\mathrm{a}}$ & 0.041 & 0.107 & - & 0.657 \\
\hline$\triangle \mathrm{FOS}$ & 0.280 & $0.280^{\mathrm{b}}$ & -0.123 & -0.312 & -0.059 & - \\
\hline Hausman test value & 9.49 & 4.44 & 5.40 & 11.13 & 4.76 & 2.79 \\
\hline p-value & 0.214 & 0.487 & 0.368 & 0.088 & 0.5357 & 0.732 \\
\hline
\end{tabular}

85 Note: a b, c refer to level of significance at $1 \%, 5 \%$ and $10 \%$. The results obtained in table 10,11 and 12 were as a

86 results of estimating equations (16) to (21).

87

88

89 


\begin{tabular}{|c|c|c|}
\hline Grouping & Long run causality & Short run causality \\
\hline \multirow[t]{7}{*}{ Main panel } & $\mathrm{CO} 2 \leftarrow G D P$ & $\mathrm{CO} 2 \leftarrow G D P$ \\
\hline & $\mathrm{CO} 2 \leftarrow N U C$ & $\mathrm{CO} 2 \leftarrow N U C$ \\
\hline & $\mathrm{CO} 2 \leftarrow R E W$ & $\mathrm{CO} 2 \neq R E W$ \\
\hline & $\mathrm{CO} 2 \leftrightarrow \mathrm{FOS}$ & $\mathrm{CO} 2 \leftrightarrow \mathrm{FOS}$ \\
\hline & $G D P \leftrightarrow N U C$ & $G D P \leftarrow N U C$ \\
\hline & $G D P \leftrightarrow R E W$ & $G D P \leftarrow R E W$ \\
\hline & $G D P \leftrightarrow \mathrm{FOS}$ & $G D P \leftrightarrow \mathrm{FOS}$ \\
\hline \multirow[t]{7}{*}{ Energy importers } & $\mathrm{CO} 2 \leftarrow G D P$ & $\mathrm{CO} 2 \leftrightarrow G D P$ \\
\hline & $\mathrm{CO} 2 \mathrm{NUC}$ & $\mathrm{CO} 2 \neq N U C$ \\
\hline & $\mathrm{CO} 2 \leftarrow R E W$ & $\mathrm{CO} 2 \leftarrow R E W$ \\
\hline & $\mathrm{CO} 2 \leftrightarrow \mathrm{FOS}$ & $\mathrm{CO} 2 \leftrightarrow \mathrm{FOS}$ \\
\hline & $G D P \leftrightarrow N U C$ & $G D P \neq N U C$ \\
\hline & $G D P \leftrightarrow R E W$ & $G D P \leftrightarrow R E W$ \\
\hline & $G D P \leftrightarrow \mathrm{FOS}$ & $G D P \leftrightarrow \mathrm{FOS}$ \\
\hline \multirow[t]{7}{*}{ Energy exporters } & $\mathrm{CO} 2 \leftrightarrow G D P$ & $E M S \leftarrow G D P$ \\
\hline & $\mathrm{CO} 2 \leftarrow N U C$ & $E M S \leftarrow N U C$ \\
\hline & $\mathrm{CO} 2 \leftarrow R E W$ & $E M S \leftarrow R E W$ \\
\hline & $\mathrm{CO} 2 \leftrightarrow \mathrm{FOS}$ & $\mathrm{CO} 2 \leftarrow$ FOS \\
\hline & $G D P \leftarrow N U C$ & $G D P \leftarrow N U C$ \\
\hline & $G D P \leftrightarrow R E W$ & $G D P \leftrightarrow R E W$ \\
\hline & $G D P \leftrightarrow \mathrm{FOS}$ & $G D P \leftarrow$ FOS \\
\hline
\end{tabular}

91 Note: $\mathrm{CO}_{2}$, NUC, REW, FOS and GDP symbolized $\mathrm{CO}_{2}$ emissions, nuclear energy, renewable energy, fossil fuel and gross 92 domestic product respectively. $\neq, \leftarrow$ and $\leftrightarrow$ indicates no, one way and two way causality.

93

94

95

96

97

98

99

100

101

102

103

104

105

106 
Table 15: Panel VECM granger causality results

\begin{tabular}{|c|c|c|c|c|c|c|c|c|c|c|c|c|}
\hline \multirow[t]{3}{*}{$\begin{array}{l}\text { Dependent } \\
\text { variables }\end{array}$} & \multicolumn{12}{|c|}{ Source of causality (Independent Variables) } \\
\hline & $\Delta \mathrm{CO}_{2}$ & $\Delta \mathrm{GDP}$ & $\triangle \mathrm{NUC}$ & $\triangle \mathrm{REW}$ & $\triangle \mathrm{LAB}$ & $\Delta \mathrm{FOS}$ & $\begin{array}{l}\Delta \mathrm{CO}_{2} \\
\mathrm{ECT}\end{array}$ & $\begin{array}{l}\Delta \mathrm{GDP} \\
\mathrm{ECT}\end{array}$ & $\begin{array}{c}\triangle \mathrm{NUC} \\
\mathrm{ECT}\end{array}$ & $\begin{array}{c}\triangle \mathrm{REW} \\
\mathrm{ECT}\end{array}$ & $\begin{array}{c}\triangle \mathrm{LAB} \\
\mathrm{ECT}\end{array}$ & $\begin{array}{c}\Delta \mathrm{FOS} \\
\mathrm{ECT}\end{array}$ \\
\hline & \multicolumn{6}{|l|}{ Wald test } & \multicolumn{6}{|c|}{ Wald test } \\
\hline \multicolumn{13}{|c|}{ All countries } \\
\hline$\Delta \mathrm{CO}_{2}$ & - & 0.12 & $4.15^{\mathrm{a}}$ & $2.11^{\mathrm{b}}$ & 1.13 & $3.01^{\mathrm{b}}$ & & $2.26^{\mathrm{b}}$ & $21.32^{\mathrm{a}}$ & 0.98 & 1.64 & $13.98^{\mathrm{a}}$ \\
\hline$\Delta \mathrm{GDP}$ & 0.21 & - & $2.17^{\mathrm{b}}$ & $3.01^{\mathrm{b}}$ & $3.79^{\mathrm{b}}$ & $3.27^{\mathrm{b}}$ & 3.79 & - & $79.91^{\mathrm{a}}$ & $13.67^{\mathrm{b}}$ & $3.73^{b}$ & $141.64^{\mathrm{b}}$ \\
\hline$\triangle \mathrm{LAB}$ & $2.15^{\mathrm{c}}$ & 0.02 & - & 0.03 & 0.22 & 0.42 & 0.48 & $4.16^{\mathrm{a}}$ & - & 0.46 & 0.47 & 0.46 \\
\hline$\triangle \mathrm{NUC}$ & 1.80 & $4.14^{\mathrm{a}}$ & 0.21 & - & 0.13 & 0.32 & 1.02 & $5.27^{\mathrm{a}}$ & 0.54 & - & 1.16 & 0.99 \\
\hline$\triangle \mathrm{REW}$ & 1.46 & 0.91 & $3.22^{b}$ & $3.38^{b}$ & - & 0.42 & 0.99 & 0.26 & 1.38 & 0.98 & - & 0.97 \\
\hline$\triangle \mathrm{FOS}$ & $2.78^{b}$ & 0.12 & 0.58 & $2.69^{b}$ & 0.25 & - & $10.16^{\mathrm{a}}$ & $2.74^{b}$ & 0.23 & 1.64 & $10.23^{\mathrm{a}}$ & - \\
\hline \multicolumn{13}{|c|}{ Energy importers } \\
\hline$\Delta \mathrm{CO}_{2}$ & - & $3.11^{\mathrm{b}}$ & 2.46 & $3.22^{\mathrm{b}}$ & 0.16 & $2.21^{\mathrm{c}}$ & - & 4.28 & $13.57^{\mathrm{a}}$ & 0.55 & 0.95 & $12.99^{\mathrm{a}}$ \\
\hline$\triangle \mathrm{GDP}$ & $2.29^{\mathrm{b}}$ & - & 0.34 & $2.91^{\mathrm{a}}$ & 0.30 & $2.55^{\mathrm{b}}$ & $3.52^{\mathrm{a}}$ & - & $47.79^{\mathrm{a}}$ & $8.94^{b}$ & $3.37^{\mathrm{a}}$ & $7.49^{\mathrm{a}}$ \\
\hline$\Delta \mathrm{LAB}$ & 0.55 & 0.08 & - & 0.33 & 0.28 & 0.32 & 0.73 & 0.29 & - & 0.48 & 0.77 & 0.73 \\
\hline$\triangle \mathrm{NUC}$ & 0.82 & 0.18 & 0.18 & - & 0.18 & 0.10 & 1.89 & $3.53^{c}$ & 0.50 & - & 1.73 & 0.79 \\
\hline$\triangle \mathrm{REW}$ & 2.86 & -0.52 & 2.53 & 0.36 & - & 0.14 & 1.44 & 0.29 & 1.14 & 0.57 & - & 0.13 \\
\hline$\Delta \mathrm{FOS}$ & 0.75 & 0.66 & 0.35 & 0.91 & 0.36 & - & $10.91^{\mathrm{a}}$ & $3.86^{\mathrm{a}}$ & 0.61 & 5.57 & $9.68^{\mathrm{a}}$ & - \\
\hline \multicolumn{13}{|c|}{ Energy exporters } \\
\hline$\Delta \mathrm{CO}_{2}$ & - & 1.15 & 0.39 & 1.49 & 0.57 & $3.34^{\mathrm{b}}$ & - & 0.32 & $5.58^{\mathrm{b}}$ & 1.16 & 1.61 & $6.27^{b}$ \\
\hline$\Delta \mathrm{GDP}$ & $2.19^{c}$ & - & $1.89^{c}$ & $2.46^{\mathrm{b}}$ & 0.23 & 2.53 & 3.53 & - & $17.51^{\mathrm{b}}$ & $5.54^{\mathrm{a}}$ & $4,22^{\mathrm{a}}$ & $3.38^{c}$ \\
\hline$\triangle \mathrm{LAB}$ & 0.52 & 0.06 & - & 0.93 & 0.29 & 0.73 & 0.79 & 0.58 & - & 0.28 & 1.36 & 0.22 \\
\hline$\triangle \mathrm{NUC}$ & $3.19^{c}$ & 0.45 & 0.55 & - & 0.68 & 0.88 & 0.86 & 0.28 & 1.86 & - & 0.54 & 0.19 \\
\hline$\triangle \mathrm{REW}$ & 0.27 & 0.82 & 0.09 & 0.17 & - & 0.17 & 0.13 & 0.43 & 0.74 & 0.15 & - & 0.16 \\
\hline$\Delta \mathrm{FOS}$ & 0.56 & $5.16^{\mathrm{a}}$ & 1.28 & 0.18 & 0.64 & - & $7.84^{\mathrm{a}}$ & 2.06 & 0.78 & 1.18 & $5.60^{\mathrm{a}}$ & - \\
\hline
\end{tabular}

108 NOTE: a, b, c indicates level of significance at $1 \%, 5 \%$ and $10 \%$

109

110

111

112

113

114

115

116

117

118

119 


\section{Figures}

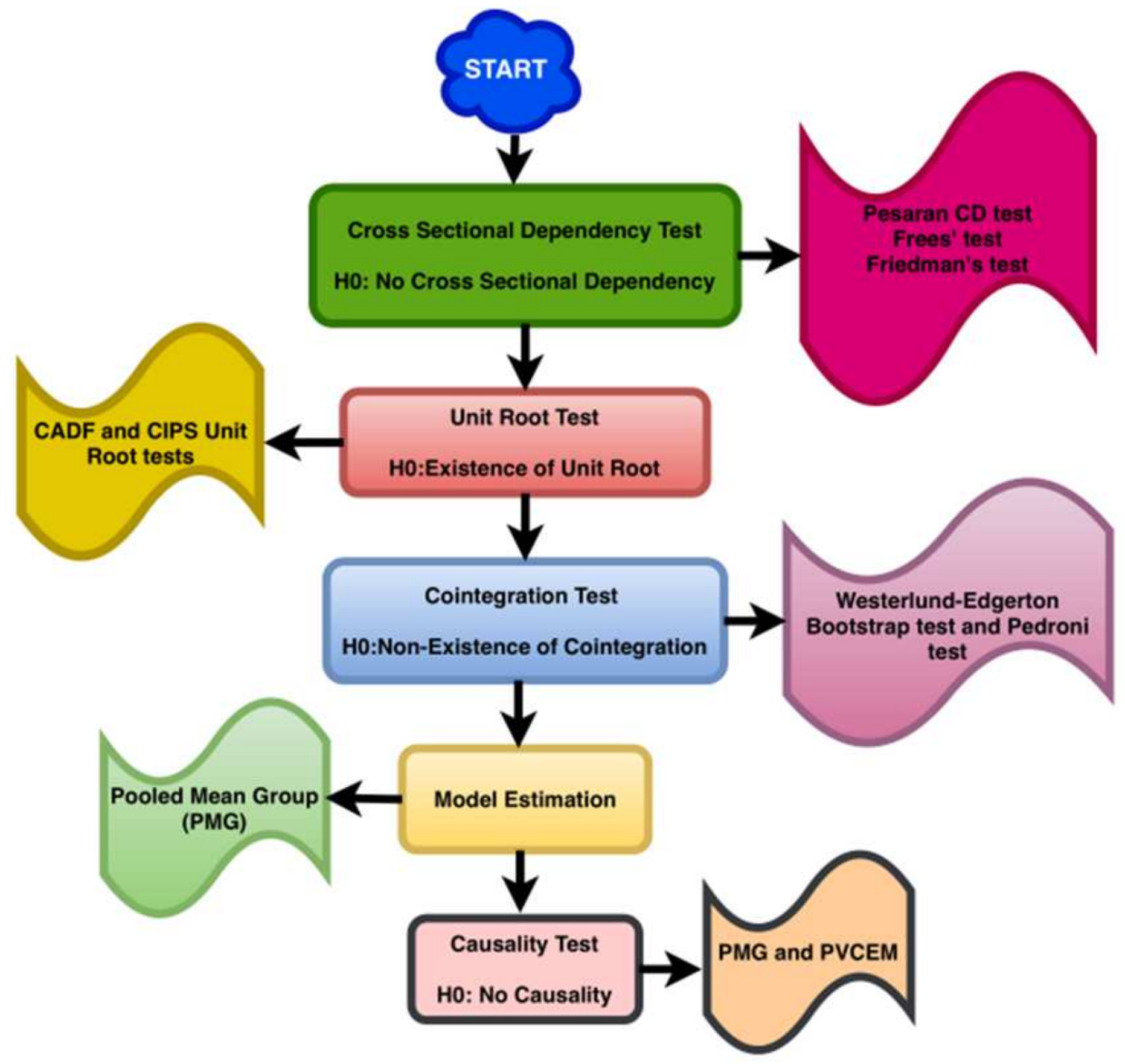

Figure 1

Graphical representation of the econometric approach. 


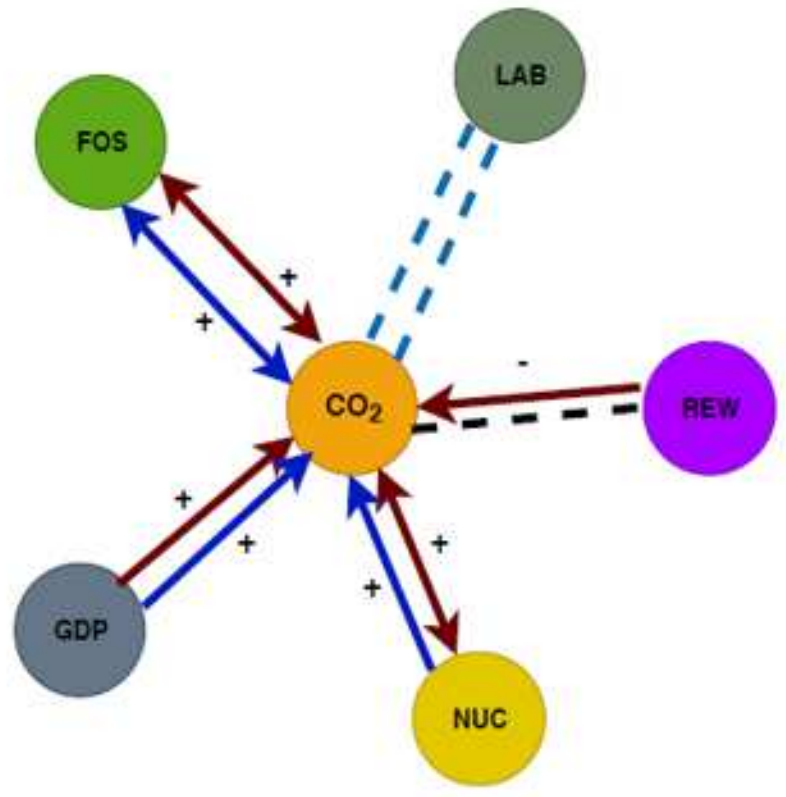

BRI COUNTRIES

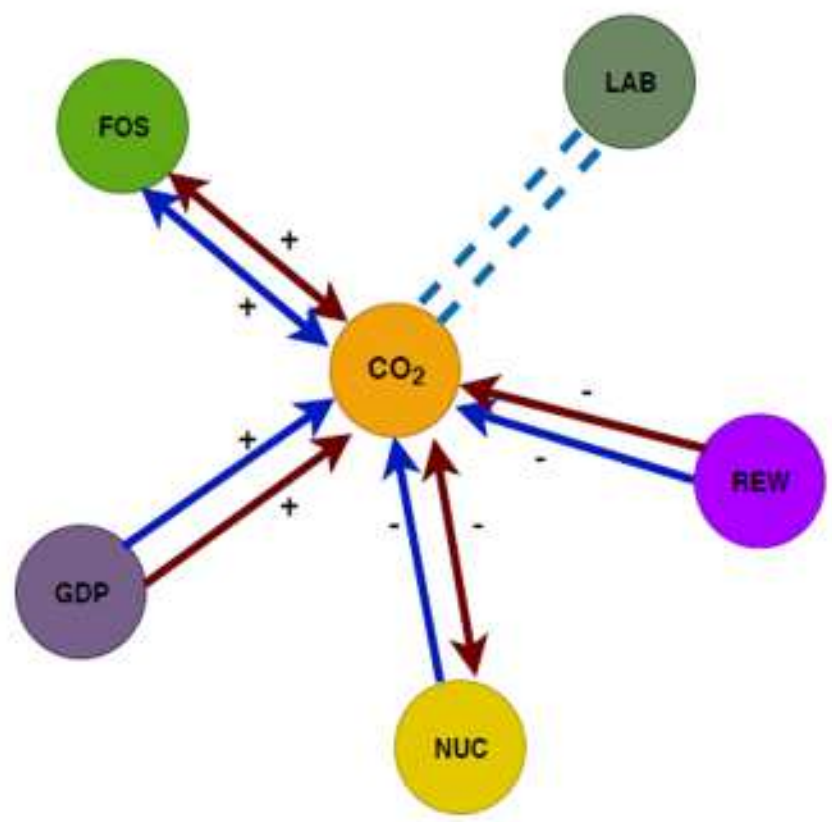

ENERGY EXPORTERS

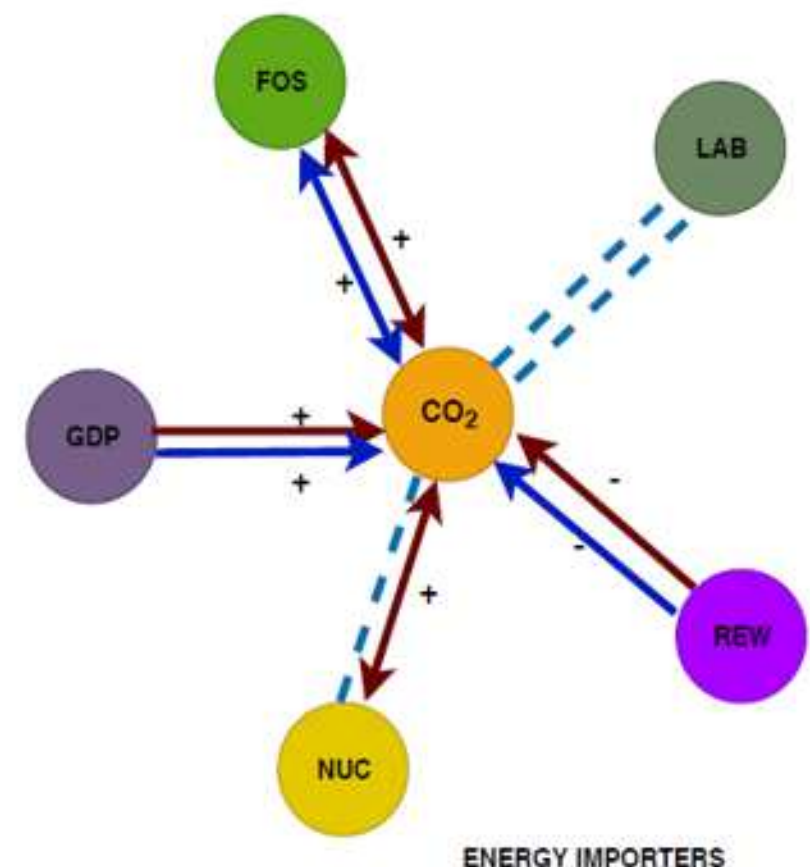

ENERGY IMPORTERS

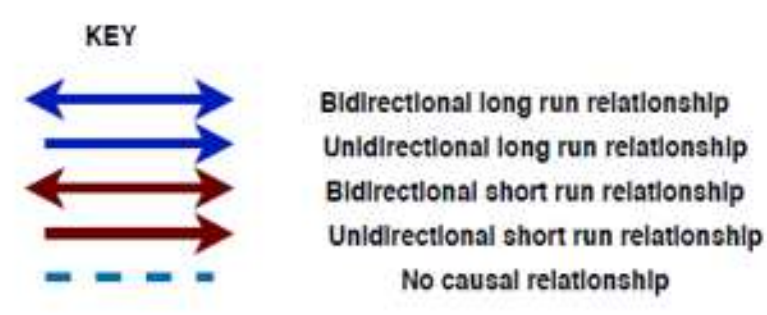

Figure 2

Graphical representation of two-sided and one sided causal affiliations among variables in different country group. 